\title{
Ecomicrobiology and microbial assimilative capacity of the oligotrophic Andean Lake Laja, Chile
}

\author{
Ecomicrobiología y capacidad asimilativa microbiana del lago \\ oligotrófico andino Laja, Chile
}

\author{
BERNHARD KARRASCH ${ }^{1, \text { * }}$, STEFAN WOELFL ${ }^{3}$, ROBERTO URRUTIA ${ }^{2}$, JENNY GONZÁLEZ ${ }^{2}$, \\ CLAUDIO VALDOVINOS ${ }^{2}$, HERNÁN CID $^{2} \&$ OSCAR PARRA $^{2}$ \\ ${ }^{1}$ UFZ - Helmholtz Centre for Environmental Research, Brückstraße 3a, D-39114 Magdeburg, Germany \\ ${ }^{2}$ Centro EULA-Chile, Universidad de Concepción, Casilla 156-C, Concepción, Chile \\ ${ }^{3}$ Instituto de Ciencias Marinas y Limnológicas, Universidad Austral de Chile, Casilla 567, Valdivia, Chile \\ ${ }^{*}$ Corresponding author: bernhard.karrasch@ufz.de
}

\begin{abstract}
A strong socio-economic development pressure in South Chile will more and more cause an impact to the present lakes and rivers. Nevertheless, our knowledge concerning the ecological structure and the microbial self-purification capabilities of these lacustrine water bodies is scant but essential for a future sustainable development of land and water use. We studied Lake Laja, a lake already heavily impacted by water diversions for hydropower generation and irrigation. Typical for the Andean region Lake Laja is an oligotrophic water body, limited by nitrogen nutrients. Only very low chlorophyll a and particulate organic carbon (POC) concentrations and a small abundance and biomass of bacteria (mainly ultramicrobacteria) and heterotrophic flagellates were encountered. Weak trophic interrelations were derived from a high bacteria-to-heterotrophic flagellate ratio. For the ten investigated extracellular enzymes (alkaline phosphatase, leucine-, arginine-, glycine- and tyrosine-aminopeptidase, $\alpha$-, $\beta$-D-glucosidase, $\alpha$-, $\beta$-D-galactosidase, $\mathrm{N}$-acetyl$\beta$-D-glucosaminidase), with the exception of $\alpha$-D-glucosidase, a broad range of organic matter degradation activities was proven. Probably, due to the N-limitation, organic nitrogen hydrolysing extracellular enzymes reached activities on average of $45 \%$ compared to other studies in oligotrophic waters. The possible effect of N-limitation on extracellular enzyme activities was more pronounced by cell specific extracellular enzymatic activity rates, which exceeded those of other oligotrophic water bodies on average by factor 2 . The overall activities of all microbial extracellular enzymes studied proved to be dominated by the dissolved free external enzymes (up to $98 \%$ ) over the ectoenzymes which are associated with particulate organic matter (bacterial cell walls, particles, and aggregates). It is concluded that future socio-economic changes, dealing with watershed human intervention (accelerating inorganic and organic loads) as well as global change (temperature and precipitation changes) could lead to significant changes in the ecology of Lake Laja.
\end{abstract}

Key words: bacterioplankton, extracellular enzymes, heterotrophic flagellates, N-limitation, phytoplankton.

\section{RESUMEN}

La gran presión generada por el desarrollo socioeconómico del sur de Chile, está causando cada vez más un mayor impacto en los lagos y ríos allí presentes. Sin embargo, el conocimiento de la estructura ecológica y la capacidad microbiana de autodepuración de los cuerpos de agua lacustres es escasa, pero esencial para un futuro uso sostenible de los recursos agua y suelo. Se estudió el lago Laja, por ser un cuerpo de agua muy afectado por la extracción de agua para la generación de energía hidroeléctrica y el riego. Como es característico de la región andina, el lago Laja es oligotrófico limitado por nutrientes nitrogenados. Se encontraron bajas concentraciones de clorofila a y carbono orgánico particulado (POC), así como bajas abundancias y biomasa de bacterias (principalmente ultramicrobacteria) y de flagelados heterotróficos. Interrelaciones tróficas débiles se determinaron de la relación bacterias y flagelados heterotróficos. Para las diez enzimas extracelulares estudiadas (fosfatasa, leucina-, arginina-, glicina- y tirosina-aminopeptidasa, a-, b-D-glucosidasa, a-, b-Dgalactosidasa, N-acetyl-b-D-glucosaminidasa), con la excepción de a-D-glucosidase, se analizó un amplio rango de actividad de degradación sobre la materia orgánica. Probablemente, debido a la limitación de nitrógeno, el N-orgánico hidrolizado por enzimas extracelulares alcanzó una actividad promedio de $45 \%$, comparada con otros estudios en aguas oligotróficas. El posible efecto de la limitación de $\mathrm{N}$ en la actividad enzimática extracelular, fue más pronunciado en las tasas de la actividad enzimática extracelular específicas, las cuales excedieron en un factor promedio de dos a las de otros cuerpos de aguas oligotróficos. En general, la actividad de todas las enzimas extracelulares microbianas estudiadas resultaron estar dominadas por enzimas externas disueltas libres (hasta el $98 \%$ ), más que por ectoenzimas asociadas a partículas de materia orgánica (paredes celulares de bacterias, partículas y agregados). De esta manera es posible concluir que los futuros cambios socioeconómicos, reflejados en el incremento de cargas orgánicas e inorgánicas, así como el efecto del cambio global (cambios en temperaturas y precipitaciones), podrían provocar cambios significativos en la ecología del lago Laja.

Palabras clave: bacterioplancton, enzimas extracelulares, fitoplankton, flagelados heterotróficos, limitación de N. 


\section{INTRODUCTION}

Viruses, bacteria, autotrophic phytoplankton, protozoans, and microzooplankton as main components of pelagic ecosystems, are responsible for the production and transfer of carbon and energy within the water column (e.g., Cole et al. 1988, Fuhrman 1999). In these processes the relative importance of the microbial food web is linked to the trophic state of the water attaining its highest significance in oligotrophic systems where nutrients are rapidly limited and regenerated (Azam et al. 1983, Burns \& Schallenberg 1998).

The role of bacteria in aquatic ecosystems is in the first place, defined by their enzymatic capacities which represent the first step of organic matter degradation (Overbek 1991, Romaní \& Sabater 1999, Karrasch 2003a). Extracellular enzyme activities are essential for the regeneration of nutrients and the breakdown of polymer particulate and dissolved organic compounds (Hoppe 1983, Chróst 1991, Karrasch et al. 2003b). These processes are a rate-limiting step for both the growth of the bacteria and for the microbial breakdown of particulate and dissolved organic material in aquatic systems (Chróst 1991, Karrasch et al. 2003a, 2003b).

Since the ecological structures and functioning, as well as energy and material fluxes of planktonic systems strongly depend on the nutrient composition and concentration (e.g., Azam et al. 1983, Weisse 1991, Stockner \& MacIsaac 1996) oligotrophic waters are highly sensitive to changes in nutrient loadings, especially eutrophication processes (Weisse, 1991, Burns \& Schallenberg 1998). Any intensification of use of a watershed or an oligotrophic lake can induce an increase of the trophic condition in various forms of eutrophication and contaminant enrichment (Weisse 1991).

The structure, assimilative capacities and ecological functioning of plankton in lakes and reservoirs, particularly in the northern hemisphere as well as in Australia and Africa, have been fairly well investigated (e.g., Baigún \& Marinone 1995, Wetzel 2001). However, scant attention has been paid so far to the geomorphological and physico-chemical features of lacustrine systems in South America, especially from ecoregions within the Andes
(Pedrozo et al. 1993, Diaz et al. 1998). Due to the high altitude, these lakes are subjected to strong winds, pronounced temperature variations during the day and strong intensities of solar and UV radiation (Villafañe et al. 1999, Aguilera et al. 2006 and literature cited therein) and exhibit a high scientific and conservation challenge (Myers et al. 2000). This eminently applies to knowledge of their microbial food web structures and ecosystem services. Hence this study ought to contribute to an enhanced knowledge about Andean water bodies and to compare and review their physicochemistry and ecomicrobiology.

For this reason we have chosen the Andean Lake Laja in Southern Central Chile, which suffers from heavy physical and hydrological interventions in the form of water diversions for hydropower generation and irrigation, affecting the natural limnological properties of the lake since 1958. Thus, a further emphasis of this study was to carry out a baseline investigation of the planktological state of the Lake Laja as a starting-point for the ascertainment of the future ecological development of this lake. This is especially required in terms of the expected socio-economic development pressure for its watershed and the lake itself. The prospective land use changes at Lake Laja will be accompanied, besides elevated inputs of inorganic, by augmented introductions of organic matter. Therefore, we additionally conducted quantifications of the first step of the biological assimilative capacities via extracellular enzymes within this Andean lake. In order to achieve an upper limit of the microbial degradation activities of organic matter, we conducted the investigation during the end of the summer period. Due to warm water temperatures during summer the ecological sensitivity to inorganic nutrient loads is also elevated.

\section{METHODS}

\section{Study site}

The Lake Laja (Fig. 1) is located at $36^{\circ} 54^{\prime} \mathrm{S}$ and $71^{\circ} 05^{\prime} \mathrm{W}$ in the Chilean Andes (altitude $1346 \mathrm{~m}$ ) and represents, within the Biobío region of South Central Chile (region VIII), the largest and socioeconomically (generation of hydropower, reservoir for irrigation of agriculture and forestry) most important lake (Parra 1996). Its watershed comprises $975 \mathrm{~km}^{2}$ with very little human 
settlement. Hydrological features are an annual average precipitation of around $2170 \mathrm{~mm}$, a maximum lake length over $33 \mathrm{~km}$, a surface area up to ca. $87 \mathrm{~km}^{2}$ with a corresponding water volume of $4.7 \mathrm{~km}^{3}$, a maximal depth of $134 \mathrm{~m}$ (mean depth $54 \mathrm{~m}$ ) during periods of low water abstraction and high-precipitations and/or high amounts of meltwater. The Lake Laja basin is an elongated river valley with lateral tributaries, drowned by a natural lava-dam built up during an eruption episode of Antuco Volcano, about 130000 B.P. (Brüggen 1941).

The lake receives water mainly by small streams and the water is draining off through the porous lava-dam at the end of the lake branch with sample station 1 and 3 (Fig. 1). For the generation of hydropower since 1959, water is released through two artificial tunnel channels into the Laja River (Parra 1996). Overall lake water discharges of approx. $320 \mathrm{~m}^{3} \mathrm{~s}^{-1}$ takes place resulting in a water residence time of 170 days. Lake stage data reveal fluctuations of 15 to $40 \mathrm{~m}$ among years (Vargas \& Alarcón 2001, Valdovinos et al. 2007).

\section{Sampling}

The sample locations were selected in order to reflect different pelagic areas of Lake Laja from a profound water column (station $3 ; 70 \mathrm{~m}$ ) across medium water depths (station $1 ; 45 \mathrm{~m}$ ) to two shallow locations, station $2(15 \mathrm{~m})$ and station $4(12 \mathrm{~m})$ located in the lee of the Antuco volcano. The investigations were carried out during 16 and 17 March 2001. Profiles of temperature and conductivity were recorded with an Idronaut multi-probe Ocean Seven 316. The water samples were taken with a Ruttner sampler and immediately analysed in a laboratory which was installed near by the lake.

\section{Laboratory analysis}

All nutrient analyses $\left(\mathrm{NO}_{3}\right.$ : cadmium reduction method; $\mathrm{NO}_{2}$ : colorimetric method; $\mathrm{NH}_{4}$ : phenate method; ortho-phosphate $\left(0-\mathrm{PO}_{4}\right)$ : ascorbic acid method) were determined according to APHA (1998). For the calculation of dissolved inorganic nitrogen (DIN) partly no ammonia values were available (below the detection limit of $7 \mu \mathrm{g} \mathrm{N}-\mathrm{NH}_{4}$ ). In this circumstance, the detection limit was used, thus in these cases the DIN values as well as DIN:oPO $\mathrm{PO}_{4}$ ratios are overestimated in Table 1 .

The particulate organic carbon (POC) concentration was determined by the catalytic oxidation of the samples and subsequent infrared spectrometry (Sharp 1974). As a measure of the phytoplankton biomass chlorophyll a (Chl. a) was determined according to Parsons et al. (1984) by the fluorometric technique using a Turner Designs Model 10-005 fluorometer (665 nm corrected by turbidity [750 $\mathrm{nm}$ ] and phaeopigments [after acidification]). Samples for POC and Chl. a analyses were filtered (1-2 L) onto Whatman $\mathrm{GF} / \mathrm{F}$ glass fibre filters (for POC annealed at $450{ }^{\circ} \mathrm{C}$ for two hours) and stored frozen $\left(-18{ }^{\circ} \mathrm{C}\right)$ until the determination. Chl. a was extracted (at $20{ }^{\circ} \mathrm{C}$ in the dark for 24 hours) with acetone.

Bacterial abundance and biomass were determined according to Hobbie et al. (1977) using the acridine orange direct count technique (AODC). $5 \mathrm{~mL}$ of the samples (preserved with $0.2 \mu \mathrm{m}$ filtered glutaraldehyde, 2 vol\%) were filtered $(<180 \mathrm{~mm} \mathrm{Hg})$ onto irgalan

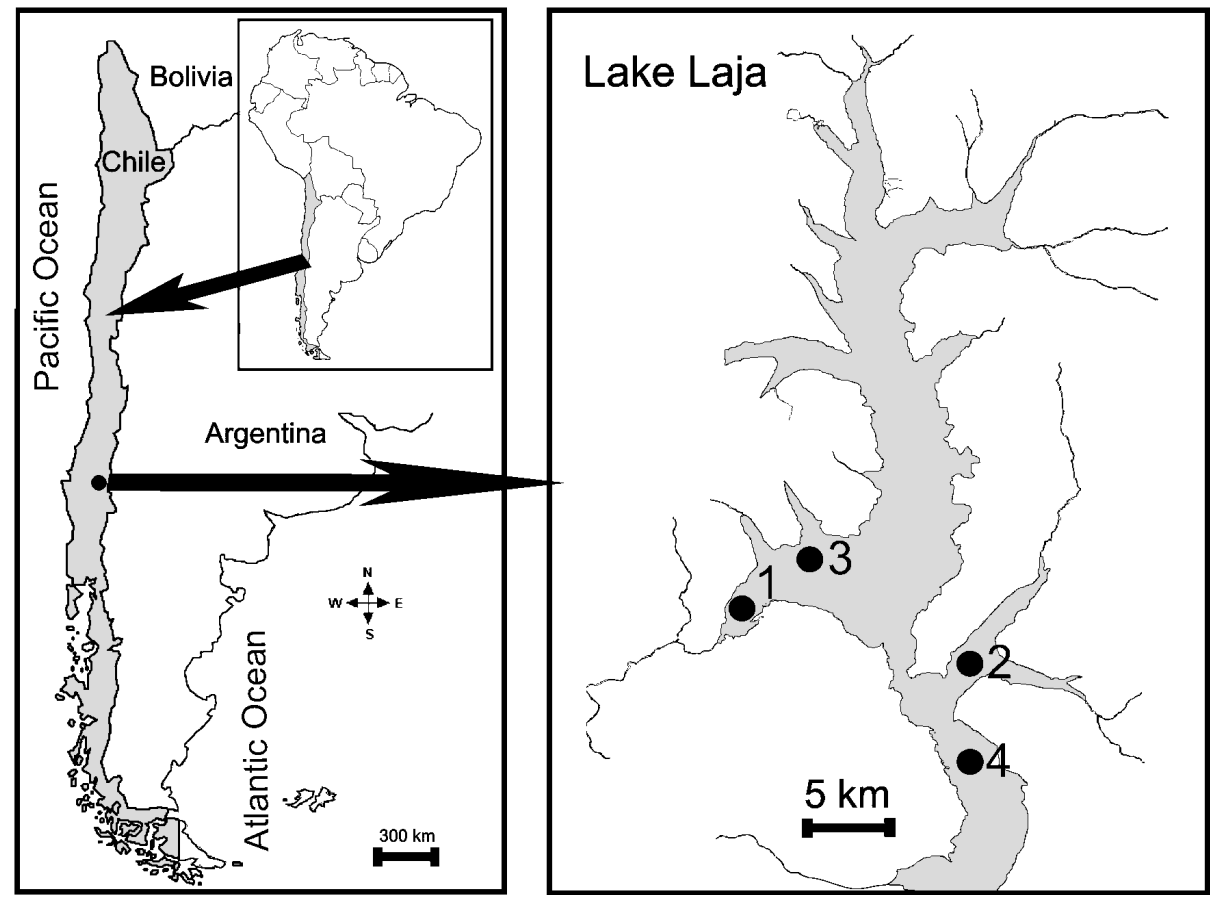

Fig. 1: Study area location at Lake Laja.

Área de estudio y localización del lago Laja. 
black stained polycarbonate Nuclepore filters $(0.2 \mu \mathrm{m}$ pore size) and $1 \mathrm{~mL}$ acridine orange (Sigma Aldrich, final conc. $0.01 \%$ ) was added. After a staining time of five minutes, the filters were vacuum-filtered, dried, and immediately counted using a Zeiss Axioplan epifluorescence microscope. A minimum of 250 bacteria cells per sample were counted. Bacterial biomass was calculated from cell size measurements (50 cells per sample) (New Porton grid G12, Graticules Ltd.) using a non-linear equation derived from Simon and Azam (1989):

$$
\text { cell carbon }=\text { cell volume }{ }^{0.59} \times 88.6 \times 1.04878
$$

The AODC counts didn't include structured cells, which were identified in a subsequent Lake Laja investigation (2002) as picocyanobacteria (Karrasch et al. in preparation). Additionally, the picocyanobacteria could be distinguished from the bacteria by their significantly larger cell dimensions leading to an average cell volume $\pm \mathrm{SD}\left(0.2 \pm 0.03 \mu \mathrm{m}^{3}\right)$ compared $0.04 \pm 0.01$ $\mu \mathrm{m}^{3}(\mathrm{n}=1000)$ of bacteria.
The abundance and biomass of heterotrophic flagellates (preserved with $0.2 \mu \mathrm{m}$ filtered glutaraldehyde, 2 vol.\%) were determined using the proflavine method (Haas 1982). With the exception of the filtered volume $(20-50 \mathrm{~mL}$ ) and fluorochrome (circa $0.3 \%$ proflavine; Sigma Aldrich), the same filter type, handling and microscopic equipment were used as described for the bacterial counts. A factor of $0.22 \mathrm{pg} \mathrm{C}$

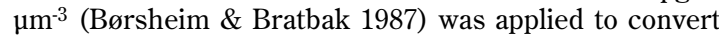
the cell volume to cell carbon. For the ascertainment of the phytoplankton abundance we used the Utermöhl (1958) technique.

The maximum hydrolysis rates of extracellular enzymes (alkaline phosphatase, leucine-, arginine-, glycine- and tyrosine-aminopeptidase, $\alpha-, \beta-D-$ glucosidase; $\alpha-, \beta-D$-galactosidase; $N$-acetyl- $\beta-D$ glucosaminidase) were determined fluorometrically in accordance with Hoppe (1983) using the fluorescence tracer 4-methylcoumarinyl-7-amide (MCA) for the analogue substrates containing amino acids and 4-methylumbelliferyl (MUF) for the remaining substrate

Vertical distribution of nitrate $\left(\mathrm{NO}_{3}\right)$, nitrite $\left(\mathrm{NO}_{2}\right)$, ammonium $\left(\mathrm{NH}_{4}\right)$, dissolved inorganic nitrogen (DIN), orthophosphate $\left(\right.$ o- $\left.\mathrm{PO}_{4}\right)$, silicate $\left(\mathrm{SiO}_{2}\right)$ DIN:o- $\mathrm{PO}_{4}$ ratio, particulate organic carbon (POC) and chlorophyll a in Lake Laja. * = DIN calculation using the ammonia detection limit concentration $\left(7 \mu \mathrm{g} \mathrm{NH} \mathrm{NH}_{4} \mu \mathrm{g} \mathrm{N} \mathrm{L}^{-1}\right)$ thus the values are overestimated and representing the upper possible DIN concentration, ${ }^{\#}=$ due to DIN concentration which are based on the use of the ammonia detection limit raised DIN: $\mathrm{oPO}_{4}$ ratios, n.a. = not analysed.

Distribución vertical de nitrato $\left(\mathrm{NO}_{3}\right)$, nitrito $\left(\mathrm{NO}_{2}\right)$, amonio $\left(\mathrm{NH}_{4}\right)$, nitrógeno inorgánico disuelto (DIN), ortofosfato $\left(\right.$ o- $\left.\mathrm{PO}_{4}\right)$, silicatos $\left(\mathrm{SiO}_{2}\right)$, DIN:razón o-PO $\mathrm{PO}_{4}$, carbono orgánico particulado (POC) y clorofila a en el Lago Laja. * $=$ DIN cálculo considerando el límite de detección de concentración de amonio $\left(7 \mu \mathrm{g} \mathrm{NH}_{4} \mu \mathrm{g} \mathrm{N} \mathrm{L} \mathrm{L}^{-1}\right)$, por lo que los valores están sobreestimados y representan la concentración DIN más alta posible, \# = debido a la concentración DIN, la cual se basó en el límite de detección de amonio, razones DIN: $\mathrm{oPO}_{4}$ proporciones, n.a. = no analizado.

\begin{tabular}{|c|c|c|c|c|c|c|c|c|c|c|}
\hline Station & $\begin{array}{l}\text { Depth } \\
\text { (m) }\end{array}$ & $\begin{array}{c}\mathrm{NO}_{3} \\
\left(\mu \mathrm{g} \mathrm{N} \mathrm{L}^{-1}\right)\end{array}$ & $\begin{array}{c}\mathrm{NO}_{2} \\
\left(\mu \mathrm{N} \mathrm{L}^{-1}\right)\end{array}$ & $\begin{array}{c}\mathrm{NH}_{4} \\
\left.(\mu \mathrm{g} \mathrm{N} \mathrm{L})^{-1}\right)\end{array}$ & $\begin{array}{c}\text { DIN } \\
\left(\mu g \mathrm{~N} \mathrm{~L}^{-1}\right)\end{array}$ & $\begin{array}{c}0-\mathrm{PO}_{4} \\
\left(\mu \mathrm{g} \mathrm{PL}^{-1}\right)\end{array}$ & $\begin{array}{c}\mathrm{SiO}_{2} \\
\left(\mathrm{mg} \mathrm{SiO}_{2} \mathrm{~L}^{-1}\right)\end{array}$ & DIN:o-PO ${ }_{4}$ & $\begin{array}{c}\text { POC } \\
\left(\mathrm{mg} \mathrm{C} \mathrm{L}^{-1}\right)\end{array}$ & $\begin{array}{l}\text { Chl. a } \\
\left(\mu g \mathrm{~L}^{-1}\right)\end{array}$ \\
\hline \multirow{6}{*}{1} & 0 & 0.68 & 0.91 & $<7$ & $8.59^{*}$ & 0.49 & 13.97 & $7.92^{\#}$ & 0.4 & 0.63 \\
\hline & 5 & 1.70 & 0.24 & 11 & 12.94 & 0.39 & 13.48 & 14.98 & 0.5 & 1.32 \\
\hline & 10 & 0.69 & 0.21 & $<7$ & $7.90^{*}$ & 0.60 & 13.44 & $5.95^{\#}$ & 0.4 & 1.94 \\
\hline & 20 & 1.00 & 0.21 & 26 & 27.21 & 0.51 & 13.33 & 24.09 & 0.3 & 1.53 \\
\hline & 45 & 29.4 & 0.09 & $<7$ & $36.49^{*}$ & 3.21 & 13.38 & $4.85^{\#}$ & 0.1 & 0.31 \\
\hline & 1 & 0.79 & 0.33 & 14 & 15.12 & 1.04 & 12.92 & 6.57 & 0.3 & 0.55 \\
\hline \multirow[t]{3}{*}{2} & 8 & 0.85 & 0.18 & 12 & 13.03 & 0.74 & 13.02 & 7.95 & 0.5 & 1.53 \\
\hline & 15 & 1.19 & 0.30 & 60 & 61.49 & 1.04 & 13.11 & 26.70 & 0.4 & 0.72 \\
\hline & 1 & 0.40 & 0.21 & $<7$ & $7.61^{*}$ & 0.77 & 12.84 & $4.46^{\#}$ & 0.4 & 1.28 \\
\hline \multirow[t]{4}{*}{3} & 8 & 0.72 & 0.24 & $<7$ & $7.96^{\star}$ & 0.77 & 12.80 & $4.67^{\#}$ & 0.3 & 0.97 \\
\hline & 15 & 0.56 & 0.18 & 10 & 10.74 & 0.87 & 12.81 & 5.58 & 0.4 & 0.56 \\
\hline & 70 & n.a. & n.a. & n.a. & n.a. & n.a. & 12.90 & n.a. & 0.2 & n.a. \\
\hline & 1 & 0.45 & 0.21 & 78 & 78.66 & 0.91 & 12.76 & 39.04 & 0.3 & 1.07 \\
\hline \multirow[t]{2}{*}{4} & 6 & 0.53 & 0.24 & $<7$ & $7.77^{\star}$ & 0.75 & 12.77 & $4.68^{\#}$ & 0.6 & 1.38 \\
\hline & 12 & 2.17 & 0.27 & $<7$ & $9.44^{*}$ & 1.41 & 13.07 & $3.02^{\#}$ & 0.5 & 0.53 \\
\hline
\end{tabular}


analogues. Determinations of the extracellular enzyme activities were carried out by adding $1000 \mu \mathrm{M}$ of the analogue substrates to $200 \mu \mathrm{L}$ samples and incubated in micro-plates for $24 \mathrm{~h}$ in the dark at in situ temperatures. Enzyme activities were measured using a micro-plate fluorescence reader (Labsystems, Ascent) at $364 \mathrm{~nm}$ (excitation) and $445 \mathrm{~nm}$ (emission). The maximum hydrolysis rates were calculated using internal standard additions.

To divide the overall extracellular enzyme activities into ectoenzyme and free dissolved external enzyme activities, a size-fractionated 'prefiltration' $(<-24 \mathrm{kPa})$ was performed using $0.2 \mu \mathrm{m}$ Nuclepore polycarbonate filters. The enzyme activities were determined as described above. The $<0.2 \mu \mathrm{m}$ fraction defines extracellular enzymes, which are free dissolved in the water (external enzymes). The fraction of ectoenzymes was calculated from the difference of overall extracellular enzyme activity versus the activity of free dissolved external enzymes. Ectoenzymes represent enzymes, which are associated with particles (free living bacteria, particle-bound bacteria, and originally free dissolved enzymes adsorbed onto particle surfaces).

\section{RESULTS}

For the deeper stations we determined a strong thermal stratification between 10 to $35 \mathrm{~m}$ (Fig. 2) of the water column. The more shallow stations exhibit only a very weak thermocline commencing at around 5 to $10 \mathrm{~m}$. Overall temperature profiles (station 1 and 3 ) ranged from summertime $18{ }^{\circ} \mathrm{C}$ down to $5{ }^{\circ} \mathrm{C}$ ("wintertime" deepwater). With around 9-24 $\mu \mathrm{S}$ $\mathrm{cm}^{-1}$ a very low conductivity was estimated.

Referring to Table $1 \mathrm{~N}$ and $\mathrm{o}-\mathrm{PO}_{4}$ showed no strong vertical gradients, mainly for the sediment near sampling points where elevated concentrations were found. In all very low $\mathrm{N}$ (0.4-29.4 $\mathrm{\mu g} \mathrm{NO}_{3}-\mathrm{N} \mathrm{L} \mathrm{L}^{-1}, 0.1-0.9 \mu \mathrm{g} \quad \mathrm{NO}_{2} \mathrm{~N} \mathrm{~L}^{-1}$, $\left.<7.0-78.0 \mu \mathrm{g} \mathrm{NH}_{4} \mathrm{~N} \mathrm{~L}^{-1}\right)$ and $0-\mathrm{PO}_{4}(0.4-3.2 \mu \mathrm{g}$ o- $\left.\mathrm{PO}_{4}-\mathrm{P} \mathrm{L} \mathrm{L}^{-1}\right)$ concentrations were determined. Concerning the molar ratio of DIN:o- $\mathrm{PO}_{4}$ only at station $1(20 \mathrm{~m})$, station $2(15 \mathrm{~m})$, and station $4(1 \mathrm{~m})$ a molar DIN:o- $-\mathrm{PO}_{4}$ quotient of $>16$ (range: 24-39), were calculated. For all other sample locations, a strong N-limitation (3-8, once 15) predominated. With $12.8-14.0 \mathrm{mg} \mathrm{SiO}_{2}$ very high and vertically, almost uniformly, distributed silicate concentrations were found.

POC concentrations (Table 1) exhibited a relative homogenous vertical and horizontal distribution ranging from 0.1-0.6 mg POC L-1 with highest concentrations at the lower limit of the epilimnion. A more pronounced vertical distribution can be observed for chlorophyll a attaining a concentration range of 0.3 -
$1.9 \mu \mathrm{g}$ Chl. a $\mathrm{L}^{-1}$ with highest values at the surface (station 3 ) or at the beginning of the thermocline (Table 1$)$.

For the abundance $\left(0.6-1.7 \times 10^{9}\right.$ cells $\left.\mathrm{L}^{-1}\right)$ and biomass (6.9-24.1 $\left.\mu \mathrm{g} \mathrm{C} \mathrm{L}^{-1}\right)$ of bacteria (Fig. 3) a weak distinct vertical structuring was found. Generally, highest concentrations were determined for the upper water column, but with one exception, not matching the Chl. a maxima. The distribution of abundance (0.4-0.6 × $10^{6}$ cells $\left.\mathrm{L}^{-1}\right)$ and biomass (0.05-0.12

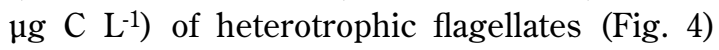
exhibited only slight differences within their vertical pattern and between the stations. The resulting abundance ratios of bacteria versus heterotrophic flagellates ranged between 1400$4000($ mean \pm SD $[2600 \pm 760, \mathrm{n}=15])$.

Overall, a low pico- and microphytoplankton abundance with 21-404 cells $\mathrm{mL}^{-1}$ were estimated (Table 2). The phytoplankton was dominated by Bacillariophyceae (29-90\%) and Chlorophyceae (7-70 \%). Significantly lower shares to the phytoplankton abundance were attained from Chrysophyceae, Cyanophyceae, Cyrptophyceae, and Dinophyceae.

Except for $\alpha$-D-glucosidase, where only once a hydrolysis activity was measurable (data not shown), all other determined total extracellular enzyme activities were detectable at every station. Highest total enzymatic activities were determined for the four aminopeptidase activities (Fig. 5-7) ranging overall from 2.04.4 (glycine-aminopeptidase, Fig. 6), -11.9 (leucine-aminopeptidase, Fig. 5), -16.3 (arginine-aminopeptidase, Fig. 5), -19.4 $\mu \mathrm{g} \mathrm{C}$ $\mathrm{L}^{-1} \mathrm{~h}^{-1}$ (tyrosine-aminopeptidase, Fig. 5). Lower importance with maximum enzymatic activities of $<2.5 \mu \mathrm{g} \mathrm{C} \mathrm{L} \mathrm{L}^{-1} \mathrm{~h}^{-1}$ were established in a decreasing sequence of their means (Fig. 6-7) for N-acetyl$\beta$-D-glucosaminidase $(0.9$, maximum $=2.45 \mu \mathrm{g} \mathrm{C}$ $\left.\mathrm{L}^{-1} \mathrm{~h}^{-1}\right), \beta$-D-glucosidase $(0.8$, maximum $=1.9 \mu \mathrm{g}$ $\left.\mathrm{C} \mathrm{L} \mathrm{L}^{-1} \mathrm{~h}^{-1}\right), \alpha$-D-galactosidase $(0.4$, maximum $=0.8$ $\left.\mu \mathrm{g} \mathrm{C} \mathrm{L}^{-1} \mathrm{~h}^{-1}\right)$, alkaline phosphatase (0.4, maximum $\left.=0.5 \mu \mathrm{g} \mathrm{C} \mathrm{L}^{-1} \mathrm{~h}^{-1}\right)$, and $\beta$-D-galactosidase $(0.3$, maximum $\left.=0.8 \mu \mathrm{g} \mathrm{C} \mathrm{L}^{-1} \mathrm{~h}^{-1}\right)$.

A comparison (Table 3) of EEA minimum and maximum rates as well as specific EEA (related to the bacterial abundance) with published results from lakes and from the Biobío river (to have at least one reference for glycine-, tyrosine-, arginineand aminopeptidases as well as for $\alpha$-D- 
galactosidase) displays the following: With two exceptions ( $\mathrm{N}$-acetyl- $\beta$-D-glucosaminidase [minimum] and $\beta$-D-galactosidase [maximum]) overall lower EEA extreme values (factor 0.1 to 0.8 , mean $\pm \mathrm{SD}[0.2 \pm 0.14, \mathrm{n}=22]$ ) were determined in this study. Concerning the specific EEA connected to the hydrolysis of nitrogen containing POM and DOM (N-acetyl$\beta$-D-glucosaminidase and all peptidases) and to the degradation of $\alpha$-(maximum) and $\beta$ - $\mathrm{D}$ galactose 1.1 to 58.4 (mean $\pm \mathrm{SD}[5.8 \pm 15.2$, $\mathrm{n}=16]$ ) times higher degradation rates were determined for Lake Laja. For the cleavage of all other applied hexoses and of phosphate the specific hydrolysis rates remained lower than in other studies (factor 0.1 to 0.6 , mean \pm SD [0.4 $\pm 0.3, \mathrm{n}=7 \mathrm{]})$. Among all determined parameters no significant Pearson correlations were found.
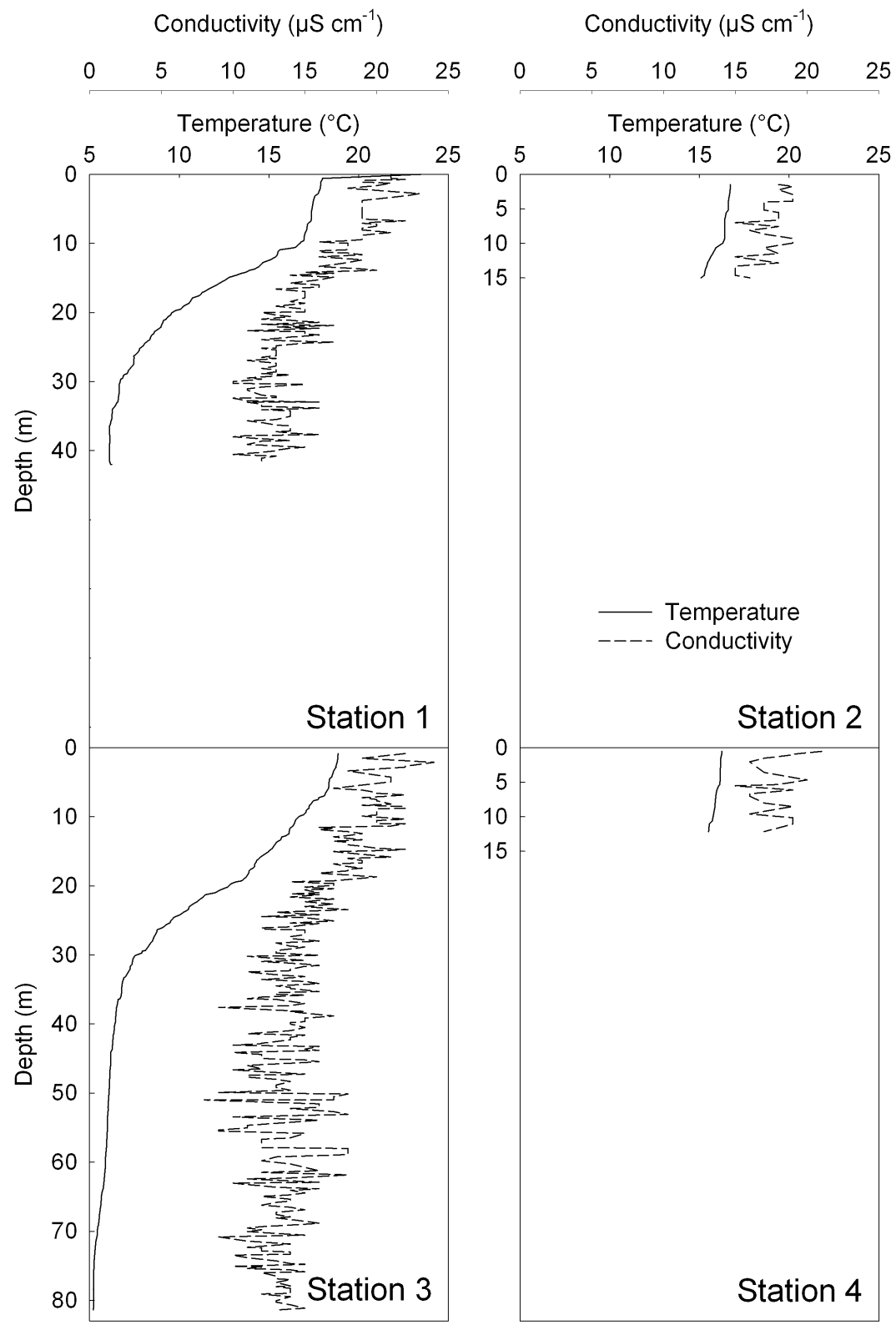

Fig. 2: Vertical distribution of temperature and conductivity in Lake Laja.

Distribución vertical de la temperatura y conductividad en el lago Laja. 

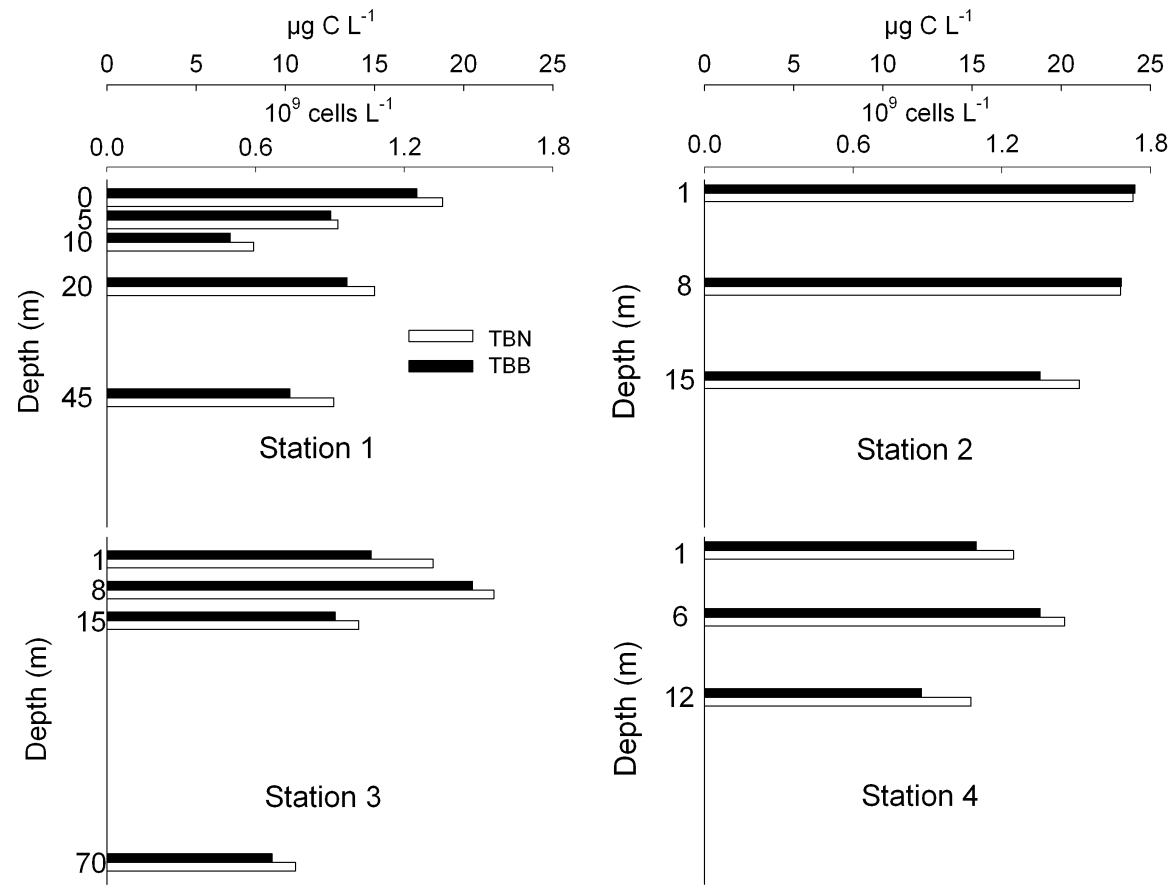

Fig. 3: Vertical distribution of total bacterial numbers (TBN) and total bacterial biomass (TBB) in Lake Laja. Distribución vertical del número total de bacterias (TBN) y de la biomasa bateriana total (TBB) en el lago Laja.
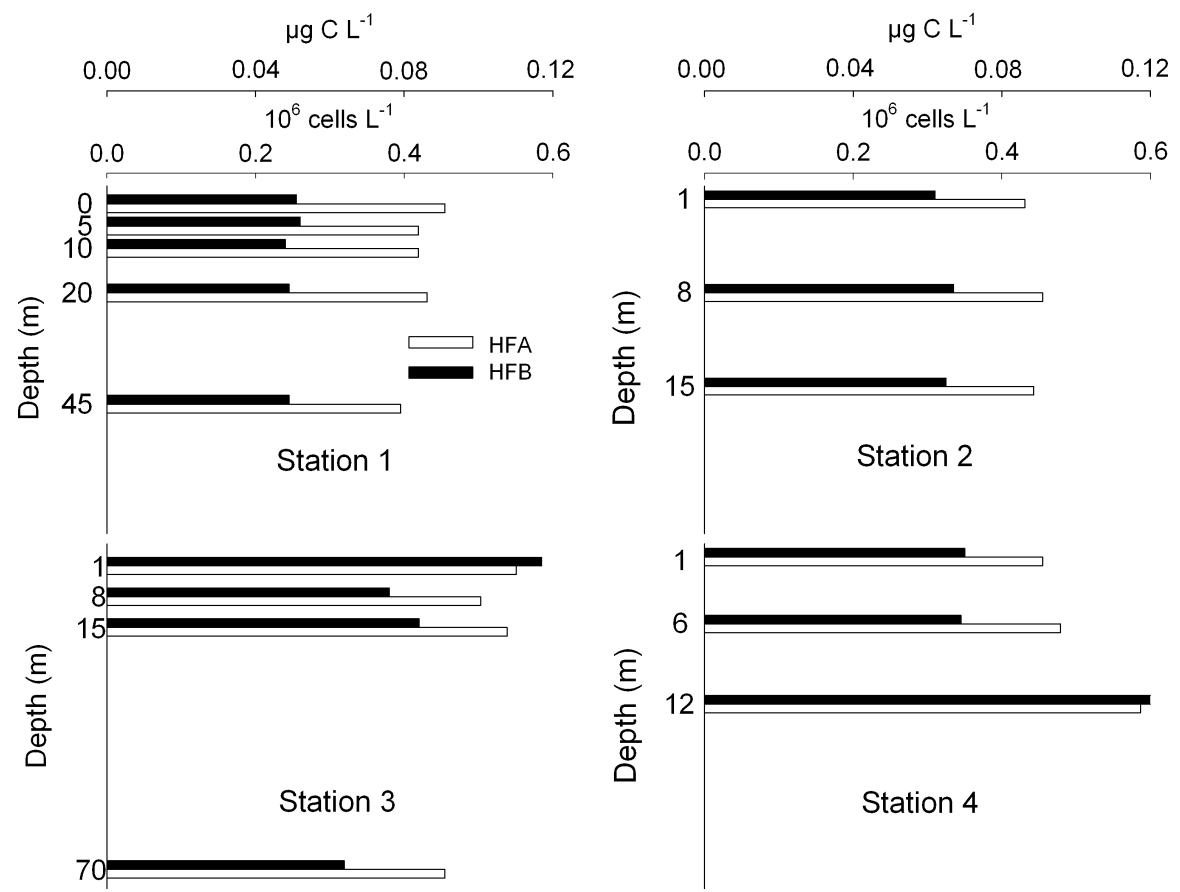

Fig. 4: Vertical distribution of heterotrophic flagellates abundance (HFA) and h heterotrophic flagellates biomass (HFB) in Lake Laja.

Distribución vertical de la abundancia de flagelados heterotróficos (HFA) y de la biomasa de flagelados heterotróficos (HFB) en el lago Laja. 
TABLE 2

Vertical abundance of phytoplankton groups in Lake Laja. Bac. = Bacillariophyceae, Chl. = Chlorophyceae, Chr. = Chrysophyceae, Cyan. = Cyanophyceae, Cry. = Cryptophyceae, Dino. = Dinophyceae, Abund. = abundance, $\%=$ relative abundance in percentage.

Distribución vertical de grupos de fitoplancton en lago Laja. Bac. = Bacillariophyceae, Chl. = Chlorophyceae, Chr. $=$ Chrysophyceae, Cyan. $=$ Cyanophyceae, Cry. $=$ Cryptophyceae, Dino. $=$ Dinophyceae, Abund.$=$ abundancia, $\%=$ abundancia relativa en porcentaje.

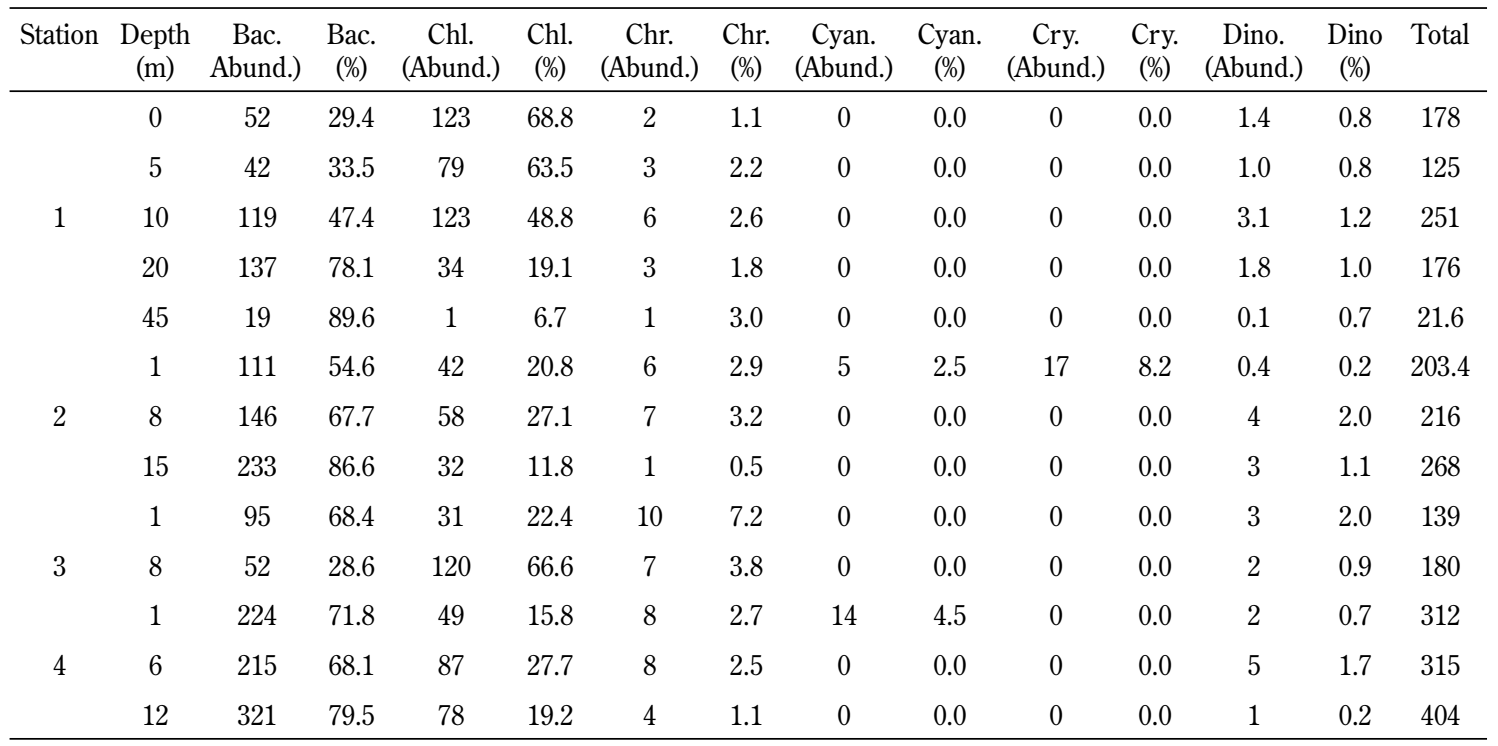
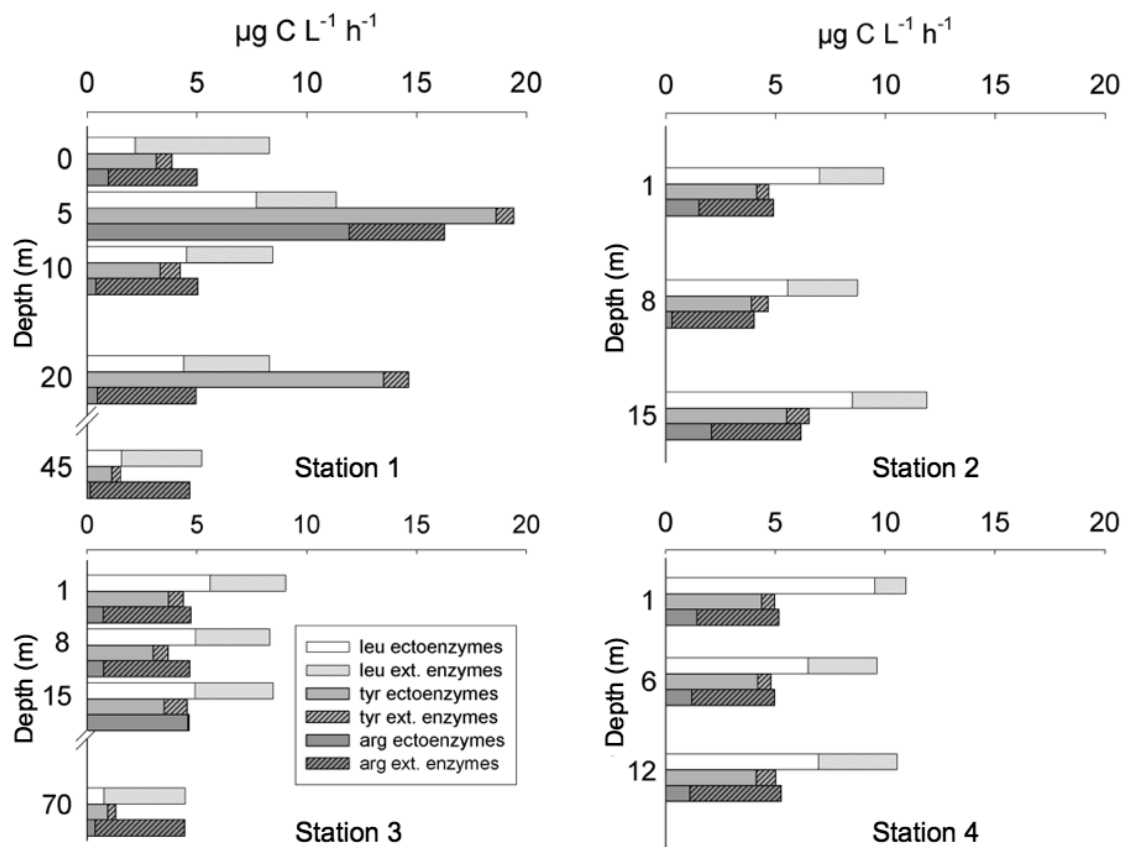

Fig. 5: Vertical distribution of hydrolysis rates of ectoenzyme and external enzyme activities in Lake Laja. leu = leucine aminopeptidase activity, tyr = tyrosine aminopeptidase activity, $\arg =$ arginine aminopeptidase activity.

Distribución vertical de las tasas de hidrólisis de ectoenzimas y actividades enzimáticas externas en el lago Laja. leu = actividad de leucina aminopeptidasa, tyr = actividad de tirosina aminopeptidasa, arg = actividad de arginina aminopeptidasa. 

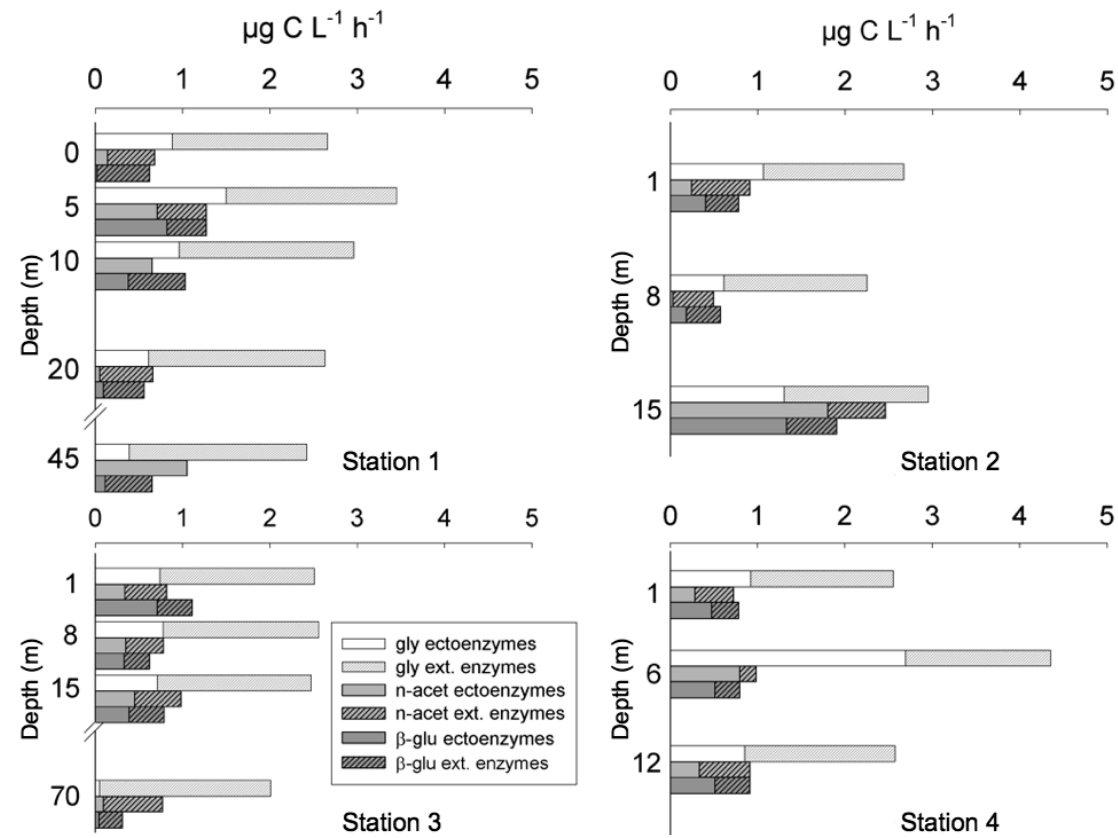

Fig. 6: Vertical distribution of hydrolysis rates of ectoenzyme and external enzyme activities in Lake Laja. gly = glycine aminopeptidase activity, $\mathrm{n}$-acet $=\mathrm{N}$-acetyl- $\beta$-D-glucosaminidase activity, $\beta$-glu $=\beta$-D-glucosidase activity. Note the compared to Fig. 5 different abscissa scale of 0 to 5 .

Distribución vertical de las tasas de hidrólisis de ectoenzimas y actividades enzimáticas externas en el lago Laja. Gly = actividad de glicina aminopeptidasa, $n$-acet = actividad de N-acetil-b-D-glucosaminidasa, b-glu = actividad b-D-glucosidasa. Tenga en cuenta en la comparación con la Fig. 5, la diferente escala de abscisas de 0 a 5.

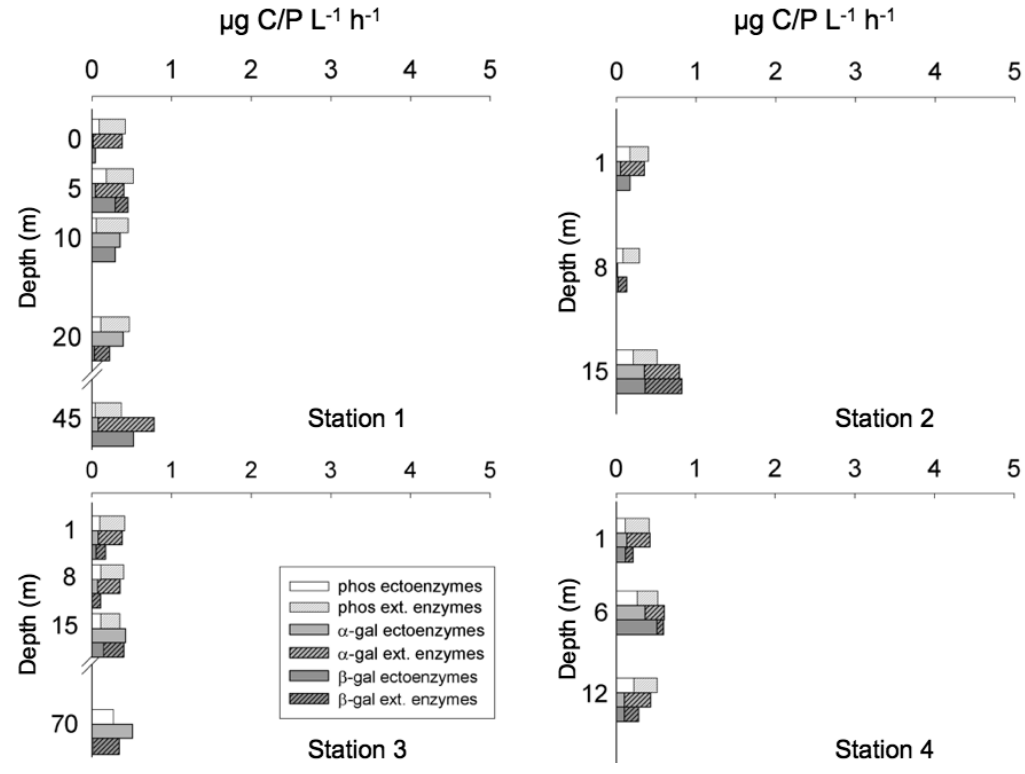

Fig. 7: Vertical distribution of hydrolysis rates of ectoenzyme and external enzyme activities in Lake Laja. phos = alkaline phosphatase activity, $\alpha$-gal $=\alpha$-D-galactosidase activity, $\beta$-gal $=\beta$-D-galactosidase activity. Note the compared to Fig. 5 different abscissa scale of 0 to 5 .

Distribución vertical de las tasas de hidrólisis de ectoenzimas y actividades enzimáticas externas en el lago Laja. phos = actividad de fosfatasa ácida, a-gal = actividad de a-D-galactosidasa, b-gal = actividad de b-D-galactosidasa. Tenga en cuenta en la comparación con la Fig. 5, la diferente escala de abscisas de 0 a 5 . 
Main hydrolysis rates can be attributed to the action of free dissolved external enzyme activities (means: 51-74 \%) spanning a range of overall $0-98 \%$. Only the degradation of $\beta$-D-galactosides (mean: $47 \%$ ) and tyrosine containing peptides (mean: $17 \%$ ) were dominated by ectoenzymes.

\section{DISCUSSION}

As for the season expectable a strong thermal stratification of the water column was detected in the deeper parts of the lake (Fig. 2). Within the shallow parts of the lake due to enhanced mixing and current processes more or less no stratification was encountered.

The conductivity of Lake Laja is in a good accordance with other lakes as well as rivers in the southern parts of the Andes, which are characterised by a very low conductivity

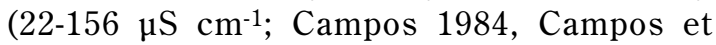
al. 1992a, 1992b, Parra et al. 1993, Pedrozo et al. 1993). Hence, except for silicate, the surface waters represent very diluted solutions caused by the igneous nature of the bedrock, small watersheds with restricted inputs of weathering products, minor anthropogenic emissions as well as minor inputs of marine aerosols and terrestrial dust (Pedrozo et al. 1993). The bedrock nature could also explain the silicate concentrations $\left(12.8-14.0 \mathrm{mg} \mathrm{\textrm {SiO } _ { 2 }}\right.$ $\left.\mathrm{L}^{-1}\right)$, which are significantly higher than the world average of silica $\left(4.9 \mathrm{SiO}_{2} \mathrm{~L}^{-1}\right.$; Meybeck 1979).

A further joint feature of Lake Laja with other lakes located in the South Andean region is the oligotrophy of their water bodies (e.g., Campos et al. 1987, 1990, Parra et al. 1993, Pedrozo et al. 1993, Steinhart et al. 2002, Woelfl et al. 2003). With o- $\mathrm{PO}_{4}$ up to $3.2 \mu \mathrm{g} \mathrm{P}^{-\mathrm{PO}_{4} \mathrm{~L}^{-1}}$ and epilimnion concentrations of $\leq 1.4 \mu \mathrm{g} \mathrm{P}^{-\mathrm{PO}_{4}}$ $\mathrm{L}^{-1}$ as well as DIN results of $\leq 78.7 \mu \mathrm{g} \mathrm{N} \mathrm{L}^{-1}$ their concentrations remained below the upper range of oligotrophic classification of o- $\mathrm{PO}_{4}$ of $<15.0$ $\mu \mathrm{g} \mathrm{P}_{-} \mathrm{PO}_{4} \mathrm{~L}^{-1}$ and nitrogen nutrients of $<300.0$ $\mu \mathrm{g} \mathrm{N} \mathrm{L} \mathrm{N}^{-1}$ (Klapper 1991) and of < $1630 \mu \mathrm{g} \mathrm{N} \mathrm{L}{ }^{-1}$ (Wetzel 2001).

Very noticeable is the high share of ammonia as the main inorganic nitrogen source. While, due to ammonia assimilation by bacteria and phytoplankton and because of nitrification, some samples showed $\mathrm{NH}_{4}-\mathrm{N}$ concentrations below the detection limit, other samples are featured with elevated ammonia concentrations. One explanation could be recent grazing and excretion activities of layered zooplankton. In subsequent Lake Laja investigations (2002 and 2003) very high abundances of crustacean and rotifers of up to 280 and 3960 individuals $\mathrm{L}^{-1}$, respectively, and a very high zooplankton biomass (crustacean and

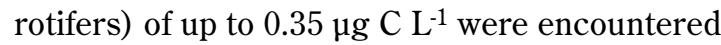
(Karrasch et al. in preparation).

Of particular importance are the low molar DIN:oPO $\mathrm{PO}_{4}$ ratios of $<16$ (range: $3-15$, mean $\pm \mathrm{SD}[6.5 \pm 3.2, \mathrm{n}=11])$, which in cases of non detectable ammonia concentrations for the DIN calculation could be lower. These depressed DIN:o $\mathrm{PO}_{4}$ ratios underline the important role of nitrogen nutrients for their control of the phytoplankton productivity, and in consideration of the oligotrophic state the extreme sensitivity of this ecosystem to any changes, especially of the inorganic nitrogen regime of the lake.

The dominating oligotrophic character and N-limitation of Andean water bodies (Pedrozo et al. 1993, Soto 2002, Karrasch et al. 2006) could be derived from minor livestock farming and a, more or less, absent agricultural activity with mainly $\mathrm{N}$ emissions (Oyarzún et al. 2002). In addition a lesser economic activity (transport, industry, energy production) as further $\mathrm{N}$ source (mainly $\mathrm{NO}_{\mathrm{x}}$; Bragazza et al. 2005) contributes also to the low inorganic nitrogen concentrations in the lakes as well as remote depositions of $\mathrm{N}$ disposals within this region (Hedin et al. 1995, Galloway et al. 1996). Due to the oligotrophic state only a small biomass can be produced autochthonously, which normally is in a causality with good oxygen conditions (Seitzinger 1988) therefore, we can assume that the depressed nitrate concentrations and low DIN:o $\mathrm{PO}_{4}$ ratios are probably not, or hardly, resulting from $\mathrm{N}$ losses via denitrification. A filling of the $\mathrm{N}$ pool by the activity of $\mathrm{N}$-fixing cyanobacteria, which could contribute a significant proportion of the $\mathrm{N}$ budget (Smith 1990 and literature cited herein), was not derivable. From our Utermöhl counts of microphytoplankton only for two surface samples (station 2 and 4) we encountered a cyanobacteria abundance (Anabaena sp.) of 30 and 55 cell ml$^{-1}$ with no nitrogen-fixing heterocysts. 
TABLE 3

Comparison of total bacterial abundance (TBN), total extracellular enzyme activities (EEA) and bacterial cell specific EEA (spec. EEA) of lakes (except Karrasch et al. 2006); $\min =$ minimum, $\max$ $=$ maximum, .. . $=$ not available, n.c. $=$ not calculable.

Comparación de abundancia bacteriana total (TBN), actividad total de enzimas extracelulares (EEA) y EAA específico de células bacterianas (spec. EAA) de lagos (except Karrasch et al. 2006); $\min =$ minimum, $\max =\operatorname{maximum}$, n.a. $=$ no disponible, n.c. $=$ no calculable.

\begin{tabular}{|c|c|c|c|c|c|c|}
\hline Enzyme/Author(s) & $\begin{array}{c}\mathrm{TBN}_{\min } \\
\left(10^{9} \text { cells L L }^{-1}\right)\end{array}$ & $\begin{array}{c}\mathrm{TBN}_{\max } \\
\left(10^{9} \text { cells L L }^{-1}\right)\end{array}$ & $\begin{array}{c}\mathrm{EEA}_{\min } \\
\left(\mu \mathrm{g} \mathrm{C} / \mathrm{P} \mathrm{L}^{-1} \mathrm{~h}^{-1}\right)\end{array}$ & $\begin{array}{c}\text { EEA }_{\max } \\
\left(\mu \mathrm{g} \mathrm{C} / \mathrm{P} \mathrm{L}^{-1} \mathrm{~h}^{-1}\right)\end{array}$ & $\begin{array}{l}\begin{array}{l}\text { Spec. } \text { EEA }_{\min } \\
\left(\text { fg cell }^{-1} \mathrm{~h}^{-1}\right)\end{array} \\
\end{array}$ & $\begin{array}{l}\text { Spec. } \text { EEA }_{\max } \\
\left(\text { fg cell }^{-1} \mathrm{~h}^{-1}\right)\end{array}$ \\
\hline \multicolumn{7}{|c|}{ N-acetyl- $\beta$ D-glucosaminidase } \\
\hline This study & 0.59 & 1.73 & 0.49 & 2.45 & 0.29 & 1.62 \\
\hline Vrba et al. (1997) & n.a. & n.a. & 0.014 & 0.893 & n.c. & n.c. \\
\hline Vrba et al. (2004) & 0.40 & 1.90 & 0.058 & 2.088 & 0.144 & 1.099 \\
\hline Nedomá et al. (1994) & 7.54 & 7.54 & 0.027 & 0.074 & 0.004 & 0.001 \\
\hline Karrasch et al. (2006) & 2.07 & 10.69 & 0.973 & 7.381 & 0.261 & 1.016 \\
\hline \multicolumn{7}{|l|}{ Leucine-aminopeptidase } \\
\hline This study & 0.59 & 1.73 & 4.46 & 11.88 & 5.20 & 14.27 \\
\hline Münster (1994) & 1.00 & 9.00 & 0.072 & 5.544 & 0.007 & 2.808 \\
\hline Richardot et al. (2001) & 0.35 & 2.45 & 0.360 & 14.760 & 1.029 & 6.024 \\
\hline Chróst \& Siuda (2006) & 2.20 & 6.10 & 0.007 & 12.960 & 0.003 & 2.125 \\
\hline Karrasch et al. (2006) & 2.07 & 10.69 & 25.496 & 117.322 & 4.571 & 17.012 \\
\hline \multicolumn{7}{|l|}{ Glycine-aminopeptidase } \\
\hline This study & 0.59 & 1.73 & 2.009 & 4.348 & 1.341 & 4.993 \\
\hline Karrasch et al. (2006) & 2.07 & 10.69 & 8.786 & 18.288 & 1.082 & 4.973 \\
\hline \multicolumn{7}{|c|}{ Tyrosine-aminopeptidase } \\
\hline This study & 0.59 & 1.73 & 1.312 & 19.421 & 1.678 & 20.813 \\
\hline Karrasch et al. (2006) & 2.07 & 10.69 & 11.306 & 52.906 & 1.886 & 7.898 \\
\hline \multicolumn{7}{|l|}{ Arginine-aminopeptidase } \\
\hline This study & 0.59 & 1.73 & 4.017 & 16.261 & 2.391 & 17.427 \\
\hline Karrasch et al. (2006) & 2.07 & 10.69 & 15.018 & 42.630 & 2.118 & 8.415 \\
\hline \multicolumn{7}{|l|}{$\alpha$-D-glucosidase } \\
\hline This study & 0.59 & 1.73 & 0.000 & 0.230 & n.c. & 0.190 \\
\hline Richardot et al. (2001) & 0.35 & 2.45 & 0.014 & 1.296 & 0.041 & 0.529 \\
\hline Vrba et al. (2004) & 0.40 & 1.90 & 0.022 & 1.800 & 0.054 & 0.947 \\
\hline Karrasch et al. (2006) & 2.07 & 10.69 & 0.000 & 3.589 & 0.000 & 0.336 \\
\hline \multicolumn{7}{|l|}{$\beta$-D-glucosidase } \\
\hline This study & 0.59 & 1.73 & 0.310 & 1.901 & 0.341 & 1.740 \\
\hline Münster et al. (1992) & 2.60 & 4.15 & 2.170 & 9.765 & 0.835 & 2.353 \\
\hline Münster (1994) & 1.00 & 9.00 & 0.007 & 8.280 & 0.007 & 1.584 \\
\hline Richardot et al. (2001) & 0.35 & 2.45 & 0.007 & 1.440 & 0.021 & 0.588 \\
\hline Vrba et al. (2004) & 0.40 & 1.90 & 0.058 & 5.616 & 0.144 & 2.956 \\
\hline Nedoma et al. (1994) & 7.54 & 7.54 & 0.125 & 13.464 & 0.017 & 1.786 \\
\hline Karrasch et al. (2006) & 2.07 & 10.69 & 1.619 & 10.727 & 0.416 & 1.452 \\
\hline \multicolumn{7}{|l|}{$\alpha$-D-galactosidase } \\
\hline This study & 0.59 & 1.73 & 0.013 & 0.792 & 0.007 & 0.852 \\
\hline Karrasch et al. (2006) & 2.07 & 10.69 & 0.521 & 3.878 & 0.144 & 0.732 \\
\hline \multicolumn{7}{|l|}{$\beta$-D-galactosidase } \\
\hline This study & 0.59 & 1.73 & 0.040 & 29.173 & 0.030 & 31.264 \\
\hline Karrasch et al. (2006) & 2.07 & 10.69 & 0.054 & 3.953 & 0.025 & 0.535 \\
\hline \multicolumn{7}{|l|}{ Akaline phosphatase } \\
\hline This study & 0.59 & 1.73 & 0.272 & 0.530 & 0.170 & 0.750 \\
\hline Münster et al. (1992) & 2.60 & 4.15 & 9.610 & 27.280 & 3.696 & 6.573 \\
\hline Münster (1994) & 1.00 & 9.00 & 4.154 & 52.866 & 1.240 & 8.370 \\
\hline Chróst \& Siuda (2006) & 2.20 & 15.80 & 0.648 & 7.200 & 0.295 & 1.180 \\
\hline Karrasch et al. (2006) & 2.07 & 10.69 & 0.140 & 1.430 & 0.016 & 0.383 \\
\hline
\end{tabular}


As a consequence of the oligotrophic conditions, likewise low chlorophyll a concentrations $\left(\max =1.9 \mu \mathrm{g}\right.$ Chl. $\left.\mathrm{a} \mathrm{L}^{-1}\right)$ were determined. This range is largely in consilience with chlorophyll a levels for other Andean Lakes published e.g., from Baigún \& Marinone (1995), Soto (2002), Villalobos et al. (2003), Baigún et al. (2006) and Woelfl (2007). Analogous to remote chlorophyll a concentrations also low POC concentrations were determined. From both sum parameters low lake productivity and low sedimentation/ export rates can be derived (Baines et al. 1994), which are positively influencing the oxygen budget in the water column and sediment.

In accord with the physicochemical general frameworks, the abundance and biomass stocks of pico- and nanoplankton reached relatively low values. Although the abundance of bacterioplankton with $0.6-1.7 \times 10^{9}$ cells $\mathrm{L}^{-1}$ attained typical concentrations for oligotrophic / mesotrophic habitats, we estimated extremely low bacterial cell volumes of around $0.04 \mu \mathrm{m}^{3}$ cell $^{-1}$, which led to a small bacterial biomass (up to $24.1 \mu \mathrm{g} \mathrm{C} \mathrm{L}^{-1}$ ). Compared to cell sizes estimated for lake bacteria (summarized by Jugnia et al. 1998) this average cell volume is in most cases lower than the minimum values of other lakes. With this size, the bacterioplankton made up solely ultramicrobacteria defined with a volume of $<0.05 \mu^{3}$ (Boenigk et al. 2006) and $<0.1 \mu^{3}$ (Schut et al. 1997, Hahn et al. 2003), respectively. Here a frequency of bacterial cell volumes of $<0.05 \mu^{3}$ cell $^{-1}=77 \%$ and $<0.1$ $\mu^{3}$ cell-1 $^{-1}=96 \%$, respectively was estimated. From executed estimations of viral abundances for this investigation (data not shown), carried out with $0.015 \mu \mathrm{m}$ filters, we found no concrete information for ultramicrobacteria with cell sizes below $<0.2 \mu \mathrm{m}$.

Some authors believe that ultramicrobacteria represent starvation-induced miniaturised forms of bacteria with no (Morita 1985) or no continuous growth (Kjelleberg et al. 1987) but the estimated relatively high extracellular enzyme activities, which are originating mainly from bacteria, indicating metabolically active bacteria. This is also supported by repeated studies of Lake Laja (2002 and 2003), where likewise a domination of ultramicrobacteria was encountered. Besides relatively high bacterial cell and biomass production rates Karrasch et al. (in preparation) estimated in addition by means of microautoradiography a for aquatic systems relatively high share $(39-97 \%$, mean \pm SD $[68 \pm 18 \%$, n = 16]) of leucine assimilating bacteria. Thus, the bacteria are very well metabolically involved in the conversion of substances and matter fluxes of the microbial loop.

A further microbiologically important criterion of pelagic eco-structures is the abundance of heterotrophic flagellates, which were determined for this lake within the typically published range $\left(10^{5}-10^{6}\right.$ cells $\mathrm{L}^{-1}$; e.g., Carrias et al. 1998). But, likewise to the bacteria, a low maximum biomass of $0.12 \mu \mathrm{g} \mathrm{C}$ $\mathrm{L}^{-1}$ was encountered. The determined flagellate biomass is significantly located under the average value of $9.6 \mu \mathrm{g} \mathrm{C} \mathrm{L}{ }^{-1}$ (e.g., from Carrick and Fahnenstiel 1989) given for oligotrophic environments.

The relationship of bacterial versus heterotrophic flagellate abundances was investigated by Sanders et al. (1992), who demonstrated a remarkably consistent numerical relationship (approx. 1000 bacteria:1 heterotrophic flagellate) in the euphotic zone of a variety of marine and freshwater systems within the oligotrophic-eutrophic continuum. With a ratio of 1400-4000:1 (mean \pm SD [2650 $\pm 760, \mathrm{n}=15]$ ) our results display only a weak coupling of trophic interactions between these organism groups. An effective "top-down" control of the heterotrophic flagellates by predation of metazooplankton (e.g., Tzaras and Pick 1994, Carrias et al. 1998) could be an important vector for this estimated weak trophical relationship. It cannot be judged if additionally the small-size of bacteria is abating the grazing pressure. Observation (e.g., from Gonzalez et al. [1990], Auer and Arndt [2001] and Boenigk et al. [2006]), points to a relationship that small bacteria $(<2 \mu \mathrm{m})$ and ultramicrobacteria respectively are to a lesser degree utilisable for the nutrition of heterotrophic flagellates.

In concordance with the limiting nutrient conditions, we estimated with 21-404 cells $\mathrm{mL}^{-1}$ only a low phytoplankton abundance. Relatively high abundances were achieved from Fragilaria crotonensis (12-81 \% of Bacillariophyceae; 11-62 \% of total phytoplankton abundance) and Sphaerocystis schroeteri (0-99 \% of Chlorophyceae; 0-58 \% of total phytoplankton abundance). From a subordinate importance 
were the appearances of, for example, Asterionella Formosa (Bacillariophyceae), Oocystis elliptica (Chlorophyceae), Dinobryon sp. (Chrysophyceae), and Ceratium hirundinella (Dinophyceae). Comparable low phytoplankton densities were estimated for lakes in the geographical vicinity of Lake Laja (Región X de los Lagos) e.g., Lake Llanquihue (Soto 2002), Lake Rancho (Campos et al. 1992a), Lake Todos Los Santos (Campos et al. 1990), Lake Villarrica (Campos et al., 1983). Except for Soto (2002) where Chrysophyceae received during January and March a dominant importance, these studies reported for the summer season likewise, a dominance of diatoms and green algae as a common feature.

Highest phytoplankton abundances within the water column were achieved at the beginning of the thermocline. This is a frequent feature of oligotrophic water bodies because the thermocline is associated with the nutricline and the light intensity still is above the compensation depth enabling a net primary productivity.

The activity of extracellular enzymes represents a key factor for the capability of aquatic systems to manage and eliminate nonliving autochthonous and allochthonous organic matter. The extracellular enzyme activity constitutes the first step of the microbiological self-purification process (Karrasch 2003a, 2003b) and concurrently the rate-limiting step in the microbial utilisation of dissolved and particulate matter in aquatic environments (cf. Chróst 1991 and cited references). Except for $\alpha$-D-glucosidase, hydrolytic activities were proven for all other determined extracellular enzyme activities. This indicates a broad range of enzymatic degradation capabilities within the water column and in reverse that the corresponding substrates also might commonly appear in the pelagic zone of this lake. This is deducible from the facts that ecosystems thermodynamically have to be organised very economical (Odum \& Barrett 2004). Hence it can be assumed that the synthesis of extracellular enzymes occurs purposive (Chróst 1991) because of the high material (e.g., C, N) and energetic costs (reduction equivalents) which are required for the production of extracellular enzymes.

Besides particulate organic matter (POM), especially dissolved organic matter (DOM) is the target of extracellular enzymes. The main DOM bulk is considered not to be readily utilizable for bacteria (e.g., Geller 1985, Wetzel 2001), particularly in inland waters where a high share of DOM has an allochthonous origin (soils and stream runoff) and already was exposed to some degradation and transformation processes (Tranvik 1992). Only a few percent $<5 \%$ of the DOM (Chróst 1991 and literature cited herein), consisting of labile oligo- to monomeric molecules originating mainly from autochthonous processes like viral lysis (Fuhrman 1999) exudations from phytoplankton (Fogg 1977, Baines \& Pace 1991) and zooplankton excretions (Lampert 1978, Jurmars et al. 1989), are easily accessible for extracellular enzymes.

The results of the EEA measurements are quoting the upper limit of the 'in-situ' assimilative capacity (Karrasch 2005) thus the results of this study can be used directly to make policy on discharge limits and as parameters for sustainable management measures for the summer season (cp. Table 3). Although Lake Laja is characterised by a relatively low abundance and biomass of bacterioplankton, the determined maximum EEA achieved, on average, one-third (for organic nitrogen hydrolysing extracellular enzymes $45 \%$ ) of the activity range reported for other oligotrophic water bodies (citations within Table 3). Only the maximum activity of $\beta$-Dgalactosidase exceeded other lake activities by far (factor 7.4).

Partly another picture has to be derived from specific EEA of Lake Laja that has to be divided in two clusters. Cluster one contains enzyme activities ( $\mathrm{N}$-acetyl- $\beta$-Dglucosaminidase, all aminopeptidases and $\alpha$ - as well as $\beta$-D-galactosidase), which were on average about factor $10 \pm 21.4$ (without $\beta$-Dgalactosidase: $1.9 \pm 0.6$ ) higher than maximum specific EEA from other oligotrophic water bodies (Table 3 ). The second cluster consists of specific EEA for the hydrolysis of glucose and phosphate and reached a lower specific activity (mean factor $0.5 \pm 0.4$ ) compared to other oligotrophic environments. An approximate explanation for cluster one could be, at least for the organic nitrogen degrading EEA, the overall nitrogen limitation of the lake. The hydrolysis of proteins and polypeptides, as well as of amino sugars (chitin) offers an accessory nitrogen 
source for the microorganisms. Furthermore, the direct use of nitrogen rich amino acids and peptides saves energy and material which otherwise would be required for the reduction of nitrogen oxides to ammonium and for the amino acid synthesis.

Compared to other investigations, the lower specific enzyme activities of $\alpha$-, $\beta$-Dglucosidases and alkaline phosphatases can be explained as follows: based on the fact that a relationship between enzyme activities and the polymeric composition of the sources of organic matter could exist (Boetius \& Lochte 1996, Boscker \& Cappenberg 1998, Sala \& Güde 1999) it could be inferred that the availability of the corresponding substrate molecules or the organismic demand for these substrates (e.g., for ortho-phosphate) was probably low.

The proportion of extracellular enzyme activities associated to cells and particles (ectoenzymes) versus dissolved free external enzymes represents an important ecological ratio (Karrasch et al. 2003a, 2003b, Karrasch 2005). A more particle-related degradation of organic material is subjected to a higher sedimentation probability, resulting in an export (sedimentation) of organic matter and of selfpurification capacities, while dissolved external enzymes remain more or less unaffected by the hydrographical situation (Karrasch et al. $2003 \mathrm{~b}$, Karrasch 2005). With up to $98 \%$ of the extracellular enzyme activity, the encountered $1^{\text {st }}$ step of the self-purification capacities of Lake Laja was mainly realised via external enzymes. The outcome of this is a relative constant level of degradation capacities within the water column, because enzyme losses via sedimentation are reduced.

In addition to this, physiological there can be derived lesser energetic costs and material requirements for the expression and synthesis of new extracellular enzymes by bacteria in order to balance enzyme losses due to sedimentation (Karrasch 2005), immobilization (Wetzel 1991) and enzyme decay (Wild et al. 1995). This can achieve a high importance during phases when extracellular enzyme producing processes are low. These processes are comprising bacterial synthesis of extracellular enzymes (e.g., Hoppe 1983, Chróst 1991) as well as the release of intracellular enzymes into the water phase like cell death (Berman \& Wynne 2005 and literature cited herein), viral lysis (e.g., Bratbak et al. 1994, Fuhrman 1999), and "sloppy feeding" and excretions of zooplankton (Lampert 1978, Jurmas et al 1989, Hoppe 1991).

With some exceptions the vertical patterns of the extracellular enzyme activities show overall an equal distribution with only a few aberrations. Indeed complex processes are involved in both the vertical distribution as well as the proportioning of the extracellular enzyme activities in size classes and their absolute activities (Overbeck 1991). In contrast to the intracellular milieu and its compartmentalisation, the activity of extracellular enzymes is controlled by a multitude of physico-chemical and biological interactions and antagonistic reactions, which mostly act suboptimally on the enzymes and their activities (Chróst 1991, Münster 1991). For aquatic systems the most relevant biophysico-chemical processes are $\mathrm{pH}$ (Francoeur \& Wetzel 2003), water chemistry and biological variables (e.g., Chappell \& Goulder 1994, Romaní \& Sabater 1999), photochemical effects on the interaction of enzymes and dissolved organic matter (Lindell \& Edling 1996, Scully et al. 2003) induction and repression of enzyme production and release (Chróst 1991, Priest 1984), supply of organic matter (Vrba 1992, Mallet \& Debroas 2001), and by the complexation and interaction with humic substances (Boavida \& Wetzel 1998) as well as clay particles (Tietjen \& Wetzel 2003).

The expected rapid socio-economic development in South Chile (Steinhardt et al. 2002) will result in significant land and water use changes and could lead to heavy environmental impacts. Due to the beautiful landscape of Lake Laja with very good conditions for skiing along the hillside of the Antuco volcanic cone and a huge zone of attraction in the vicinity (approx. $190 \mathrm{~km}$ from the cities Concepción, Talcahuano, and Hualpén (approx. 514000 habitants) we can expect for the Lake Laja watershed an intensified touristic use. Already now the diversions for hydropower generation and irrigation are burdening the system.

From the touristic development of the region, we can derive a higher emergence of inorganic nutrients for the Lake Laja (Yajima 1995). Additionally, an increase of atmospheric deposition of oxidised nitrogen 
compounds to this region (Galloway et al. 1994) is predicted for the next decades. The general vulnerability of oligotrophic waters (Weisse 1991) makes them very sensitive to increasing nutrient loadings, especially when the limiting nutrient (here, nitrogen) is rising and probably leading to an eutrophication of the lake. Undesirable effects of eutrophication are, among others, the disturbance of the oxygen budget (Wetzel 2001), changes of species compositions, elevated biomass as well as primary and secondary productivity (Klapper 1991), formation of unaesthetic (diazotrophic) cyanobacteria blooms (Berman 2001) and an increased risk for harmful algal blooms (Sellner et al. 2003, Smith 2003).

Furthermore, the emerging tourism would produce high amounts of organic sewage. Although, it could be demonstrated that the lake exhibits a relatively good selfpurification potential, the predominantly organic loads in the sewage of hotels and the municipal infrastructure could, if not fully or even only insufficiently treated, overcharge the assimilative capacity of Lake Laja. For a more sound determination of the microbial degradation potential future investigations have to include the quantification of assimilation, bacterial production, and respiration rates $(=$ elimination $=$ the final step of the microbiological self-purification process). Respective radiochemical methods are available but could not organisationally be deployed in this investigation. Additionally, we have to account for seasonal dynamic of the assimilative capacities. Winter tourism connoted a high organic waste formation during a season with low temperatures, which also reduces extracellular enzyme activities significantly.

ACKNOWLEDGMENTS: This study was kindly supported by grants of the Universidad de Concepción, Chile, and the Scientific Cooperation programme between the German Ministry of Research (BMBF, WTZ CHL 00/002) and CONICYT (Fondecyt No 1000526). This manuscript benefited from comments provided by two anonymous reviewers.

\section{LITERATURE CITED}

AGUILERA X, S DECLERCK, L DE MEESTER, M MALDONADO \& F OLLEVIER (2006) Tropical high Andes lakes: A limnological survey and an assessment of exotic rainbow trout (Oncorhynchus mykiss). Limnologica 36: 258-268
APHA (1998) Standard methods for the examination of water and wastewater. In: Clescesi LS, AE Greenbers \& AD Eaton (eds) APHA, American Public Health Association and Water Environment Federation. $20^{\text {th }}$ edition, Washington DC.

AUER B \& H ARNDT (2001) Taxonomic composition and biomass of heterotrophic flagellates in relation to lake trophy and season. Freshwater Biology 46: 959-972.

AZAM F, T FENCHEL, JG FIELD, JS GRAY, L-A MEYER-REIL \& TF THINGSTAD (1983) The ecological role of water-column microbes in the sea. Marine Ecology Progress Series 10: 257-263.

BAIGÚN C \& MC MARINONE (1995) Cold-temperate lakes of South America: Do they fit Northern Hemisphere models? Archives of Hydrobiology 135: 23-51.

BAIGÚN C, H MUGNI \& C BONETTO (2006) Nutrient concentrations and trophic state of small Patagonian Andean lakes. Journal of Freshwater Ecology 21: 449-456.

BAINS SB \& ML PACE (1991) The production of dissolved organic matter by phytoplankton and its importance to bacteria: Patterns across marine and freshwater systems. Limnology and Oceanography 36: 1078-1090.

BAINS SB, ML PACE \& DM KARL (1994) Why does the relationship between sinking flux and planktonic primary production differ between lakes and oceans? Limnology and Oceanography 39: 213226.

BERMAN T (2001) The role of DON and the effect of $\mathrm{N}: \mathrm{P}$ ratios on occurrence of cyanobacterial blooms: Implications from the outgrowth of Aphanizomenon in Lake Kinneret. Limnology and Oceanography 46: 443-447.

BERMAN T \& D WYNNE (2005) Assessing phytoplankton lysis in Lake Kinneret. Limnology and Oceanography 50: 526-537.

BOAVIDA M-J \& RG WETZEL (1998) Inhibition of phosphatase activity by dissolved humic substances and hydrolytic reactivation by natural ultraviolet light. Freshwater Biology 40: 285-293.

BOENIGK J, K PFANDL \& PJ HANSEN (2006) Exploring strategies for nanoflagellates living in a 'wet desert'. Aquatic Microbial Ecology 44: 71-83.

BOETIUS A \& K LOCHTE (1996) Effects of organic enrichments on hydrolytic potentials and growth of bacteria in deep-sea sediments. Marine Ecology Progress Series 140: 239-250.

BØRSHEIM KY \& G BRATBAK (1987) Cell volume to cell carbon conversion factors for a bacteriovorus Monas sp. enriched from seawater. Marine Ecology Progress Series 36: 171-175.

BOSCHKER HTS \& TE CAPPENBERG (1998) Patterns of extracellular enzyme activities in littoral sediments of Lake Gooimeer, The Netherlands. FEMS Microbiology Ecology 25: 79-86.

BRAGAZZA L, J LIMPENS, R GERDOL, P GROSVERNIER, M HÁJEK et al. (2005) Nitrogen concentration and $\delta^{15} \mathrm{~N}$ signature of ombrotrophic Sphagnum mosses at different $\mathrm{N}$ deposition levels in Europe. Global Change Biology 11: 106-114.

BRATBAK G, T THINGSTAD \& M HELDAL (1994) Viruses and the microbial loop. Microbial Ecology 28: 209-221.

BRÜGGEN J (1941) El Volcán Antuco y la geología glacial del valle del Laja. Revista Geológica de Chile 91: 356-386. 
BURNS CW \& M SCHALLENBERG (1998) Impacts of nutrients and zooplankton on the microbial food web of an ultra-oligotrophic lake. Journal of Plankton Research 20: 1501-1525.

CAMPOS H, W STEFFEN, C ROMÀN, L ZÚÑIGA \& G AGÜERO (1983) Limnological studies in Lake Villarrica. Morphometric, physical, chemical, planktonical factors and primary productivity. Archiv für Hydrobiologie (Suppl.) 65: 371-406.

CAMPOS H (1984) Limnological study of Aurocanian lakes (Chile). Verhandlungen - Internationale Vereinigung für Theoretische und Angewandte Limnologie 22: 1319-1327.

CAMPOS H, W STEFFEN, O PARRA, P DOMÍNGUEZ \& G AGÜERO (1987) Estudios limnologicos en el Lago Caburgua (Chile). Gayana Botánica 44: 61-84.

CAMPOS H, W STEFFEN, G AGÜERO, O PARRA \& L ZÚÑ̃IGA (1990) Limnological study of Lake Todos Los Santos (Chile) Morphometry, physics, chemistry, plankton, and primary productivity. Archiv für Hydrobiologie 117: 453-484.

CAMPOS H, W STEFFEN, G AGÜERO, O PARRA \& L ZÚÑ̃IGA (1992a) Limnology of Lake Rancho (Chile). Limnologica 22: 337-353

CAMPOS H, W STEFFEN, G AGÜERO, O PARRA \& L ZÚÑIGA (1992b). Limnological studies of Lake Rupanco (Chile) Morphometry, physics, chemistry, plankton, and primary productivity. Archiv für Hydrobiologie (Suppl.) 90: 85-113

CARRIAS J-F, C ARMBLARD, C QUIBLIER-LLOBERAS \& G BOURDIER (1998) Seasonal dynamics of free and attached heterotrophic nanoflagellates in an oligomesotrophic lake. Freshwater Biology 39: 91-101.

CARRICK HJ \& GL FAHNENSTIEL (1989) Biomass, size structure, and composition of phototrophic and heterotrophic nanoflagellate communities in Lake Huro and Michigan. Canadian Journal of Fisheries and Aquatic Sciences 46: 1922-1928.

CHAPELL KR \& R GOULDER (1994) Seasonal variation of epilithic extracellular enzyme activity in three diverse headstreams. Archiv für Hydrobiologie 130: $195-214$

CHRÓST RJ (1991) Environmental control of the synthesis and activity of aquatic microbial ectoenzymes. In: Chróst RJ (ed) Microbial enzymes in aquatic environments: 29-59. Springer Verlag, Berlin.

CHRÓST RJ \& W SIUDA (2006) Microbial production, utilization, and enzymatic degradation of organic matter in the upper trophogenic layer in the pelagial zone of lakes along a eutrophication. Limnology and Oceanography 51: 749-762.

COLE JJ, S FINDLAY \& ML PACE (1988) Bacterial production in fresh and saltwater ecosystems: a cross-system overview. Marine Ecology Progress Series 43: 1-10.

DÍAZ MM, FL PEDROZO \& PF TEMPORETTI (1998) Phytoplankton of two Araucanian lakes of differing trophic status (Argentina). Hydrobiologia 369/370: 45-57.

FOGG GE (1977) Excretion of organic matter by phytoplankton. Limnology and Oceanography 22: 576-577.

FRANCOEUR SN \& RG WETZEL (2003) Regulation of periphytic leucine-aminopeptidase activity. Aquatic Microbial Ecology 31: 249-258.

FUHRMAN JA (1999) Marine viruses and their biogeochemical and ecological effects. Nature 399: 541-548.
GALLOWAY JN, WE KEENE \& GE LIKENS (1996) Processes controlling the composition of precipitation at a remote southern hemispheric location: Torres del Paine National Park, Chile. Journal of Geophysical Research 101: 6883-6897.

GALLOWAY JN, H LEVY II \& PS KASIBHATIA (1994) Year 2020: Consequences of population growth and development on deposition of oxidized nitrogen. AMBIO 23: 120-123.

GELLER A (1985) Degradation and formation of refractory DOM by bacteria during simultaneous growth on labile substrates and persistent lake water constituents. Schweizerische Zeitschrift für Hydrologie - Swiss Journal of Hydrology 47: 27-44.

GONZÁLEZ JM, EB SHERR \& BF SHERR (1990) Size-selective grazing on bacteria by natural assemblages of estuarine flagellates and ciliates. Applied and Environmental Microbiology 56: 583589.

HAAS LW (1982) Improved epifluorescence microscopy for observing planktonic micro-organisms. Annals L'Institute Océanographique 58: 261-266.

HAHN MW, H LÜNSDORF, Q WU, M SCHAUER, MG HÖFLE, J BOENIGK \& P STADLER (2003) Isolation of novel ultramicrobacteria classified as Actinobacteria from five freshwater habitats in Europe and Asia. Applied and Environmental Microbiology 69: 1442-1451.

HEDIN LO, J ARMESTO \& AH JOHNSON (1995) Patterns of nutrient loss from unpolluted, old growth temperate forests: Evaluation of biogeochemical theory. Ecology 76: 493-567.

HOBBIE JE, RJ DALEY \& S JASPER (1977) Use of nucleopore filters for counting bacteria by fluorescence microscopy. Applied and Environmental Microbiology 33: 1225-1228.

HOPPE H-G (1983) Significance of exoenzymatic activities in the ecology of brackish water: Measurements by means of methylumbelliferyl - substrates. Marine Ecology Progress Series 11: 299-308.

HOPPE H-G (1991) Microbial extracellular enzyme activitiy: A new key parameter in aquatic ecology. In: Chróst RJ (ed) Microbial enzymes in aquatic environments: 60-83. Springer Verlag, Berlin.

JUGNIA LB, RD TADONLÉKE, T SIME-NGANDO, SM FOTO \& N KEMKA (1998) Short-term variations in the abundance and cell volume of bacterioplankton in an artificial tropical lake. Hydrobiologia 385: 113-119.

JURMAS PA, DL PENRY, JA BAROSS, MJ PERRY \& BW FROST (1989) Closing the microbial loop: Dissolved carbon pathway to heterotrophic bacteria from incomplete ingestion, digestion and absorption in animals. Deep-Sea Research 36: 483-495.

KARRASCH B, S ULLRICH, M MEHRENS \& H ZIMMERMANN-TIMM (2003a). Free and particle-associated extracellular enzyme activity and bacterial production in the Lower Elbe Estuary, Germany. Acta Hydrochimica et Hydrobiologica 31: 297-306.

KARRASCH B, G BORMKI, P HERZSPRUNG, M WINKLER \& M BABOROWSKI (2003b) Extracellular enzyme activity in the River Elbe during a spring flood event. Acta Hydrochimica et Hydrobiologica 31: 307-318.

KARRASCH B (2005) Qualifizierung und Quantifizierung der ersten Stufe der mikrobiologischen Selbstreinigung (extrazelluläre Enzymaktivität, 
EEA) in Gewässern und Indikation von Gewässerbelastungen und ökologischen Zuständen. In: Steinberg CEW, W Calmano, H Klapper \& RD Wilken (eds) Handbuch angewandte Limnologie: $1-44.24^{\text {th }}$ edition, chapter VIII-5.1, Ecomed Verlag, Landsberg.

KARRASCH B, O PARRA, H CID, M MEHRENS, $\mathrm{P}$ PACHECO, R URRUTIA, C VALDOVINOS \& C ZAROR (2006) Effects of pulp and paper mill effluents on the microplankton and microbial selfpurification capabilities of the Biobío River, Chile. Science of the Total Environment 359: 194-208.

KJELLEBERG S, M HERMANNSSON, P MÅRDÉN \& GW JONES (1987) The transient phase between growth and nongrowth of heterotrophic bacteria, with emphasis on the marine environment. Annual Revue of Microbiology 41: 25-49.

KLAPPER H (1991) Control of eutrophication in inland waters. Ellis Horwood, New York.

LAMPERT W (1978) Release of dissolved organic carbon by grazing zooplankton. Limnology and Oceanography 23: 831-834.

LINDELL M \& H EDLING (1996) Influence of light on bacterioplankton in a tropical lake. Hydrobiologia 323: $67-73$

MALLET C \& D DEBROAS (2001) Regulation of $\beta$ and $\alpha$-glycolytic activities in the sediments of a eutrophic lake. Microbial Ecology 41: 106-113.

MEYBECK M (1979) Major elements contents of river waters and dissolved input to oceans. Revue de Géologie Dynamique et de Géographie Physique 21: $215-246$.

MORITA RY (1985) Starvation and miniturisation of heterotrophs with special emphasis on maintenance of the starved viable state. In: Fletcher M \& GD Floodgate (eds) Bacteria in their natural environment: 11-131. Academic Press, New York.

MÜNSTER U (1991) Extracellular enzyme activity in eutrophic and polyhumic lakes. In: Chróst RJ (ed) Microbial enzymes in aquatic environments: 96122. Springer Verlag, Berlin.

MÜNSTER U, P EINÖ, J NURMINEN \& J OVERBECK (1992) Extracellular enzymes in a polyhumic lake: Important regulators in detritus processing. Hydrobiologia 229: 225-238.

MÜNSTER U (1994) Studies on phosphatase activities in humic lakes. Environment International 20: 49-59.

MYERS N, RA MITTERMEIER, CG MITTERMEIER, GAB DA FONSECA \& J KENT (2000) Biodiversity hotspots for conservation priorities. Nature 403: 853-858.

NAGATA T (1988) The microflagellate-picoplankton food linkage in the water column of Lake Biwa. Limnology and Oceanography 33: 504-517.

NEDOMA J, J VRBA, J HEJZLAR \& K ŠIMEK (1994) $\mathrm{N}$-acetylglucosamine dynamics in freshwater environments: Concentration of amino sugars, extracellular enzyme activities, and microbial uptake. Limnology and Oceanography 39: 10881100.

ODUM EP \& GW BARRETT (2004) Fundamentals of ecology. Fifth edition, Brooks Cole, Pacific Grove, USA.

OVERBEK J (1991) Early studies on ecto- and extracellular enzymes in aquatic systems. In: Chróst RJ (ed) Microbial enzymes in aquatic environments: $1-5$. Springer Verlag, Berlin.

OYARZÚN CE，R GODOY \& S LEIVA (2002) Depositación atmosférica de nitrógeno en un transecto valle longitudinal-cordillera de los Andes, centro-sur de Chile. Revista Chilena de Historia Natural 75: 233-243.

PARRA O, H CAMPOS, M VIGHI, W STEFFENS, G AGÜERO \& S BASUALTO (1993) Estudios limnológicos de los lagos Icalma y Galletué: Lagos de origen del río Biobío. In: Faranda $\mathrm{F} \&$ O Parra (eds) Evaluación de la Calidad del Agua y Ecología del Sistema Limnético y Fluvial del río Biobío. Serie Monografías Científicas EULA (Chile) 12: 161-188.

PARRA O (1996) El río Biobío. Cuadernos del Biobío. Volume 5. Universidad de Concepción, Concepción, Chile.

PARSONS T, Y MAITA \& CA LALLI (1984) Manual of chemical and biological methods for seawater analysis. Pergamon Press, Oxford.

PEDROZO F, S CHILLRUD, $\mathrm{P}$ TEMPORETTI \& M DÍAZ (1993) Chemical composition and nutrient limitation in rivers and lakes of northern Patagonian Andes (39.5 $-42^{\circ} \mathrm{S} ; 71^{\circ} \mathrm{W}$ ) (Rep. Argentina). Verhandlungen - Internationale Vereinigung für Theoretische und Angewandte Limnologie 25: 207-214.

PRIEST FG (1984) Extracellular enzymes. Van Nostrand Reinhold, (UK) Co. Ltd., Wokingham.

RICHARDOT M, D DEBROAS, A THOUVENOT, D SARGOS, JL BERTHON \& J DÉVAUX (2001) Influence of cladoceran grazing activity on dissolved organic matter, enzymatic hydrolysis and bacterial growth. Journal of Plankton Research 23: 1249-1261.

ROMANÍ AM \& S SABATER (1999) Epilithic ectoenzyme activity in a nutrient-rich Mediterranean river. Aquatic Sciences 61: 122-132

SALA MM \& H GÜDE (1999) Role of protozoans on the microbial ectoenzymatic activity during the degradation of macrophytes. Aquatic Microbial Ecology 20: 75-82.

SHARP JH (1974) Improved analysis for "particulate" organic carbon and nitrogen from seawater. Limnology and Oceanography 19: 984-989.

SANDERS RW, DA CARON \& U-G BERNINGER (1992) Relationships between bacteria and heterotrophic nanoplankton in marine and fresh waters: An inter-ecosystem comparison. Marine Ecology Progress Series 86: 1-14.

SCHUT F, RA PRINS \& JC GOTTSCHAL (1997) Oligotrophy and pelagic marine bacteria: Facts and fiction. Aquatic Microbial Ecology 12: 177-202.

SCULLY NM, L TRANVIK \& WJ COOPER (2003) Photochemical effects on the interaction of enzymes and dissolved organic matter in natural waters. Limnology and Oceanography 48: 1818-1824.

SEITZINGER SP (1988) Denitrification in freshwater and coastal marine ecosystems: Ecological and geochemical significance. Limnology and Oceanography 33: 702-724.

SELLNER KG, DOUCETTE GJ \& GJ KIRKPATRICK (2003) Harmful algal blooms: Causes, impacts and detection. Journal of Industrial Microbiology and Biotechnology 30: 383-406.

SIMON M \& F AZAM (1989) Protein content and protein synthesis rates of planktonic marine bacteria. Marine Ecology Progress Series 51: 201-213.

SMITH VH (1990) Nitrogen, phosphorus, and nitrogen fixation in lacustrine and estuarine ecosystems. Limnology and Oceanography 35: 1852-1859.

SMITH VH (2003) Eutrophication of freshwater and coastal marine ecosystems: A global problem. 
Environmental Science and Pollution Research 10: 126-139.

SOTO D (2002) Oligotrophic patterns in southern Chilean lakes: The relevance of nutrients and mixing depth. Revista Chilena de Historia Natural 75: 377-393.

STEINHART GS, GE LIKENS \& D SOTO (2002) Physiological indicators of nutrient deficiency in phytoplankton in southern Chilean lakes. Hydrobiologia 489: 21-27.

STOCKNER JG \& E MacISAAC (1996) British Columbia Lake Enrichment Programme: Two decades of habitat enhancement for sockeye salmon. Regulated Rivers - Research \& Management 12: 547-561.

TIETJEN T \& RG WETZEL (2003) Extracellular enzymeclay mineral complexes: Enzyme adsorption, alteration of enzyme activity, and protection from photodegradation. Aquatic Ecology 37: 331-339.

TRANVIK LJ (1992) Allochthonous dissolved organic matter as an energy source for pelagic bacteria and the concept of the microbial loop. Hydrobiologia 229: 107-114.

TZARAS A \& FR PICK (1994) The relationship between bacterial and heterotrophic flagellate abundance in oligotrophic to mesotrophic temperate lakes. Marine Microbial Food Webs 8: 347-355.

UTERMÖHL H (1958) Zur Vervollkommnung der quantitativen Phytoplanktonmethodik. Verhandlungen - Internationale Vereinigung für Theoretische und Angewandte Limnologie 9: 1-28.

VARGAS J \& B ALARCÓN (2001) Aportes al balance hídrico de la Cuenca del Laja. XV Congreso Chileno de Ingeniería Hidráulica 1: 125-132.

VALDOVINOS C, C MOYA, V OLMOS, O PARRA, B KARRASCH \& O BÜTTNER (2007) The importance of water-level fluctuation for the conservation of shallow water benthic macroinvertebrates: An example in the Andean zone of Chile. Biodiversity and Conservation 15: 3095-3109.

VILLAFAÑE VE, M ANDRADE, V LAIRANA, F ZARATTI \& EW HELBING (1999) Inhibition of phytoplankton photosynthesis by solar ultraviolet radiation: Studies in Lake Titicaca, Bolivia. Freshwater Biology 42: 215-224.

VILLALOBOS L, S WOELFL, O PARRA \& H CAMPOS (2003) Lake Chapo: A baseline study of a deep, oligotrophic North Patagonian lake prior to its use for hydroelectricity generation: II. Biological properties. Hydrobiologia 510: 225-237.

VRBA J (1992) Seasonal extracellular enzyme activities in decomposition of polymeric organic matter in a reservoir. Archiv für Hydrobiologie Beihefte Ergebnisse Limnologie 37: 33-42.

VRBA J, J KOFRO OVÁ-BOBKOVA, J PERNTHALER, K ŠIMEK, M MACEK \& R PSENNER (1997) Extracellular, low-affinity $\beta$ -N-acetylglucosaminidases linked to the dynamics of diatoms und crustaceans in freshwater systems of different trophic degree. Internationale Revue der gesamten Hydrobiologie 82: 277-286.

VRBA J, C CALLIERI, T BITTL, K SIMEK, R BERTONI, P FILANDR, P HARTMAN, J HEZLAR, M MACEK \& J NEDOMA (2004) Are bacteria the major producers of extracellular glycolytic enzymes in aquatic environments? International Review of Hydrobiology 89: 102-117.

WEISSE T (1991) The microbial food web and its sensitivity to eutrophication and contaminant enrichment: A cross-system overview. Internationale Revue der gesamten Hydrobiologie 76: 327-337.

WETZEL RG (1991) Extracellular enzymatic interactions: Storage, redistribution, and interspecific communication. In: Chróst RJ (ed) Microbial enzymes in aquatic environments: 6-28. Springer Verlag, Berlin.

WETZEL RG (2001) Limnology - lake and river ecosystems. Third edition. Elsevier Science, San Diego.

WILD D, R VON SCHULTHESS \& W GUJER (1995) Structured modelling of denitrification intermediates. Water Science and Technology 31: 45-54.

WOELFL S, L VILLALOBOS, O PARRA, W STEFFEN \& H CAMPOS (2003) Lake Chapo: A baseline study of a deep, oligotrophic North Patagonian lake prior to its use for hydroelectricity generation: I. Physical and chemical properties. Hydrobiologia 510: 217-224.

WOELFL S (2007) The distribution of large mixotrophic ciliates (Stentor) in deep North Patagonian lakes (Chile): First results. Limnologica 37: 28-36.

YAJIMA K (1995) Long-term effect of tourism on the recent upward trend of phosphorus in a shallow alpine lake, Japan. Lake \& Reservoir: Research and Management 1: 197-203. 